\title{
INTRODUÇÃO AO REGIME JURÍDICO DA INDÚSTRIA ELÉTRICA PREMISSAS GERAIS
}

\author{
Gustavo Kaercher Loureiro ${ }^{1}$
}

\section{RESUMO}

No presente estudo científico-jurídico o autor aborda criteriosamente a questão relacionada ao regime jurídico da indústria elétrica no Brasil, com especial relevo ao aporte jurídico constitucional do tema, que inclui energia elétrica, princípios aplicáveis à espécie, demanda de energia elétrica, setor industrial e importância social entre outros. Em sede conclusiva, colhe, então, os pontos não jurídicos principais, relegando a análise tipicamente jurídica para outra oportunidade.

Palavras-chave: Energia Elétrica. Indústria Elétrica. Regime Constitucional. Relevância Social.

\section{INTRODUÇÃO}

No presente estudo - dedicado àqueles que possuem formação em Direito - são apresentados alguns elementos básicos, caracterizadores da indústria elétrica, especialmente a brasileira, em suas dimensões física, técnica e econômica. Não se pretende que seja uma descrição completa, sistemática ou muito menos aprofundada desses aspectos.

Seus temas foram escolhidos a partir de uma perspectiva jurídica, ou melhor, a partir da opinião do autor acerca de quais traços empíricos do setor elétrico brasileiro são mais relevantes para uma exegese eficaz, i.e., para uma efetiva compreensão e análise crítica das normas de Direito pertinentes a este setor. $\mathrm{Na}$ base desta escolha está, de um lado, um prévio e sumário contato com as normas que tratam do setor elétrico e, de outro, um julgamento acerca de quais seriam algumas das notas características mais marcantes do setor elétrico brasileiro. Assim, seja por oferecer as premissas não jurídicas, seja por orientar-se parcialmente, na escolha destas premissas, pelo conteúdo das normas, o presente estudo pode ser 
considerado como uma introdução "fática" ao regime jurídico da indústria elétrica brasileira.

\section{TEMAS SUSCITADOS PELAS NORMAS CONSTITUCIONAIS}

Deixa-se para outra ocasião o exame acurado dos dispositivos constitucionais pertinentes ao setor elétrico e a indicação daqueles outros interessados em perspectivas mais amplas como a energia em geral (ex. art. 22, inc. IV) e indústrias energéticas (ex. art. 177). Na presente Seção são apenas colocados em evidência alguns temas e dispositivos constitucionais que possuem especial relação com a indústria elétrica, seja porque the dizem respeito diretamente, seja porque a ela se aplicam de modo específico, ainda que tenham alcance que a ultrapasse.

No âmbito dos dispositivos específicos, cabe mencionar, em primeiro lugar, a importância para a Constituição do potencial hidráulico e do seu aproveitamento para fins de geração de energia elétrica.

Inserido no contexto do uso múltiplo das águas, o potencial hidráulico parece ser a fonte de energia (elétrica) privilegiada pela Constituição que dela trata em diversos dispositivos, em conjunto com outros aspectos da indústria elétrica ou com outras "fontes renováveis" (art. 176, par. único), ou ainda de modo individualizado (ex., art. 20, inc. VIII, art. 176).

A Constituição, por outro lado, não se preocupou apenas com um aspecto ou uma fonte de energia elétrica; tratou de modo genérico da indústria elétrica, quando, p.ex., atribuiu à União Federal a exploração (direta ou indireta) dos "serviços e instalações de energia elétrica" (art. 21, inc. XII, b), sem especificar quais são uns e outros. Será conveniente, por isso, fazer algumas considerações sobre as diferentes fases da indústria, suas funções e os equipamentos ou "instalações" que a tornam possível.

No plano das normas gerais, cabe mencionar dois "temas constitucionais" que auxiliam na individuação das características técnico-econômicas a serem apresentadas a seguir: (a.) a noção constitucional de planejamento, presente no art. 
174 e (b.) a preocupação com o meio-ambiente, estampada em diversos dispositivos, e mais especificamente no art. 225 (veja-se os $\S 1^{\circ}$, inc. IV e $\S 6^{\circ}$ deste artigo). Consoante com isso, serão salientados em seguida alguns elementos do setor elétrico que guardam, pelo menos em princípio, relação com esses temas.

Seria possível encontrar muitas outras sugestões constitucionais que direcionariam uma apresentação não jurídica da indústria elétrica. Assim, por exemplo, a preocupação com a energia nuclear (art. 21, inc. XXIII; art. 22, inc. XXVI; art. 225, $\S 6^{\circ}$ ) demandaria alguns esclarecimentos sobre essa fonte de energia; a ênfase no aproveitamento de rios e massas d'água em regiões menos desenvolvidas (art. 43, $\S 2^{\circ}$, inc. IV) poderia levar a considerações sobre bacias hidrográficas e aproveitamento de potenciais hidráulicos espalhados pelo Brasil, dentre outras. Isso sem falar do que poderiam sugerir comandos constitucionais genéricos e abstratos como a necessidade de erradicação da pobreza em todo o território nacional e de eliminação das desigualdades regionais (art. $3^{\circ}$, inc. III).

A Constituição, como se vê, é rica em sugestões, e além da inspiração tirada do texto normativo, não se pode deixar de referir também as características técnicas e econômicas que o setor possui no Brasil, constituintes de suas especificidades empíricas que a Constituição pressupõe e que não pode/pretende modificar.

\section{ENERGIA, FONTE DE ENERGIA, INDÚSTRIA ENERGÉTICA, MATRIZ ENERGÉTICA E ENERGIA ELÉTRICA}

\subsection{Energia, fonte de energia, indústria energética e matriz energética}

Energia é um conceito generalíssimo e abarca uma série de fenômenos tão díspares entre si que só uma definição muito genérica pode ser empregada para dela tratar. Tradicionalmente, afirma-se que é a "capacidade de realizar trabalho".

Essa sucinta noção dá a medida do grau de abstração em que se situa qualquer discurso que pretenda tratar de energia. Como "trabalho" envolve sempre uma alteração qualquer em determinado estado de coisas, pode-se dizer é que a 
energia está sempre ligada à idéia de ação ou transformação, como condição de possibilidade delas.

A energia existe em diversíssimas formas, provoca as mais disparatadas alterações ("trabalhos") e se encontra nos mais diferentes elementos. Fala-se de energia química, energia térmica, energia solar, energia mecânica, energia nuclear e, também, em energia elétrica. Muito antes de ser manejada ou aproveitada pelo homem e de se constituir em objeto de uma ou de várias indústrias - e apenas uma pequeníssima parcela dela o é - a energia é um elemento constitutivo do universo e onde quer que se verifique uma mudança qualquer, ela está presente.

Uma nota típica fundamental da energia é a sua transformabilidade por meio de variados processos. É aliás, essa transformabilidade que está na base da indústria energética, que nada mais faz do que transformar ou "liberar" diferentes formas de energias "contidas" em certas fontes, pelo controle e aplicação nelas de determinados processos físico-químicos.

A energia solar (luz) é transformada, pelo processo de fotossíntese, em energia química, "armazenada" nas plantas (e esta é a base de todo o ciclo da energia na Terra). A energia química, por sua vez, pode ser transformada (por vários procedimentos, dentre eles a combustão) em energia térmica, ou calor. A energia térmica é conversível em energia mecânica; esta em energia elétrica. A transformação não possui, porém, uma única direção: energia elétrica converte-se em energia térmica, em energia mecânica; energia mecânica pode transformar-se em energia térmica e cosi via. Em verdade, em termos físicos a energia das diferentes fontes não é jamais "gerada", mas sempre "transformada". É, aliás, a sua (infinita e incessante) transformação que torna possível o "trabalho", ou seja, a alteração das coisas no mundo.

Ocorre, porém, que este não é o vocabulário corrente.

Afirma-se, antes, que a energia é sempre gerada ou obtida a partir de uma determinada fonte. Conquanto seja mais correto dizer-se que um determinado tipo de energia é obtido a partir de outro determinado tipo de energia contido em um 
certo elemento físico (que por sua vez, "adquiriu" essa energia por um anterior processo de transformação...) falar-se-á aqui em energia e nas suas "fontes".

Para ficar naquelas que mais se prestam ao manejo pelo homem, diz-se que petróleo, gás natural, carvão mineral, água corrente, matéria orgânica (biomassa), ar em movimento, raios solares e certos minérios radioativos são todos fontes de energia.

Com essa linguagem se quer significar que cada um destes elementos possui um tipo de energia que, devidamente liberada por variados processos, pode ser utilizada para a produção de trabalho ou para a obtenção de um outro tipo de energia que não aquele inicial, i.e., "primário". O tipo de uso energético que se fará com cada fonte bem como o processo de aproveitamento a que será submetida variam imensamente e mesmo cada fonte pode ter diferentes empregos energéticos.

A água de um rio pode ser usada para mover as pás de um moinho ou de uma turbina acoplada a um gerador. No primeiro caso, transforma-se sua energia cinética ("contida" na água corrente) em energia mecânica ("contida" na roda do moinho) que realizará o trabalho de moagem de grãos. No segundo caso, a energia potencial (da água "em repouso" armazenada no reservatório) se transforma em energia cinética (quando a água corre pelo conduto forçado que leva à turbina), que se transforma em energia mecânica (quando move as pás da turbina), a qual, finalmente, será transformada em energia elétrica, que será usada para diversas finalidades.

O petróleo e o gás natural, elementos com grandes quantidades de energia podem servir para movimentar uma frota de veículos ou para gerar energia elétrica. No primeiro caso, a energia química que contêm será, ao final de um processo de transformação, convertida em energia mecânica (movimento dos pistões de um motor). No segundo caso, estes gás e petróleo serão queimados para transformar energia química em energia térmica, a qual por sua vez será usada para movimentar as pás de uma turbina (energia mecânica) que "gerará" energia elétrica.

Como já dito, o manejo de certas fontes de energia constitui uma antiga atividade humana. Mesmo a produção de alimentos é, em certa medida, uma 
atividade de manejo e transformação de uma fonte de energia (a cana de açúcar², p.ex.) para a obtenção de energia que viabiliza o trabalho humano.

Mas o que caracteriza especificamente a chamada indústria energética é o aproveitamento sistemático e não esporádico de certas fontes de energia e o emprego nelas de certos processos de transformação para a obtenção de certos "produtos energéticos", aptos para o consumo.

Convencionalmente, coloca-se ao lado da indústria elétrica a indústria do petróleo, do gás, do carvão mineral, da cana-de-açúcar para obtenção do etanol, dentre outras. Cada uma delas, por formas e organizações diferentes, explora economicamente fontes de energia para diferentes finalidades. É importante ter presente, porém, que a rápida evolução tecnológica que proporciona o aproveitamento de novas fontes de energia não permite uma definição estanque e imóvel do que seja a "indústria energética". A cada dia que passa novas fontes e novos usos para fontes já conhecidas são descobertos. O que segue toma apenas a perspectiva usual.

Em termos muito gerais, o "iter" básico do aproveitamento de uma fonte de energia consiste na verificação de sua existência, suficiência e aptidão para aproveitamento econômico (pesquisa de reservatórios de gás, inventário de potenciais hidráulicos), obtenção do recurso energético primário ${ }^{3}$ (lavra de jazidas de carvão ou urânio, canalização de correntes d'água, cultivo e colheita de biomassa), aplicação de processos de conversão que fornecem a energia secundária ${ }^{4}$ - seja aquela de aplicação imediata, seja aquela destinada a novo processo energético antes de ser aproveitada pelo consumo (refino de petróleo para obtenção de gasolina, diesel; processamento do carvão, enriquecimento do urânio etc.) transporte e distribuição - entrega da energia ou do combustível - e consumo utilização para obtenção de outros tipos de energia.

Para que se tenha uma idéia da complexidade envolvida no trato da "indústria energética", o Balanço Energético Nacional (BEN) usa uma base de dados que considera quarenta e nove formas e grupos de energia, num conjunto total de 47 
atividades, dentre os quais produção, estoques, comércio externo, transformação, distribuição e consumo nos setores econômicos.

A interação entre as diferentes fontes e indústrias de energia é um traço que se torna cada dia mais importante e presente. Há inclusive medidas comuns para avaliar-se o potencial energético de toda e qualquer fonte de energia. Do ponto de vista produtivo, industrial e econômico, o progresso tecnológico tem permitido inúmeras relações entre as diferentes fontes. Aí elas ora são substituíveis entre si (e estão em concorrência), ora são complementares, ora são insumos para outros processos de transformação de energia.

Assim, por exemplo, o gás natural e o petróleo são é ao mesmo tempo insumos para a produção de energia elétrica e "concorrentes" seus, na medida em uma mesma tarefa, como o aquecimento de ambientes ou a cocção de alimentos pode ser realizada por equipamentos alimentados por energia elétrica, gás natural ou derivados de petróleo.

Há, porém, uma diferença interessante entre a indústria elétrica e as demais: ela é a única que se ocupa de um tipo específico de energia, a elétrica, sem se interessar pela fonte. As demais, por sua vez, não se definem pela energia que produzem mas, reversamente, pela fonte que exploram. Considerando-se isso seria possível dizer, inclusive, que a indústria elétrica é, em parte, dependente das demais indústrias energéticas, pois se aproveita do trabalho delas para obter seu insumo, na medida em que existem usinas geradoras a carvão, óleo diesel, biomassa, minérios radioativos etc.

Por fim, um conceito fundamental que propicia a primeira visão ampla da indústria energética é o de "matriz energética". Por tal se entende a consideração em conjunto de todas as fontes de energia que são objeto das diversas indústrias energéticas, segundo seus percentuais de participação no consumo energético nacional total.

Para que se tenha uma idéia mais concreta, em termos numéricos, o petróleo e seus derivados respondem por cerca de $38,7 \%$ de toda a oferta do país; em seguida 
vêm a biomassa com $29,7 \%$, a energia elétrica proveniente de fonte hidráulica com $14,8 \%$, o gás natural $(9,4 \%)$, carvão mineral $(6,3 \%)$ e o urânio, com uma participação um pouco superior a 1\% $(1,2 \%)$. Se comparada com a matriz energética mundial, em que o petróleo e seus derivados, o carvão mineral, o gás natural e o urânio respondem mais de $85 \%$ da oferta de energia (biomassa e energia de fonte hidráulica contribuem com os restantes $15 \%$ ), tem-se uma idéia da peculiaridade da posição brasileira, marcada pela presença maciça de fontes de energia renovável.

\subsection{Energia elétrica}

Elétrica é a energia relacionada com a corrente de elétrons que passa - ou, mais tecnicamente, oscila - pelos condutores de um circuito. Para bem compreender o fenômeno em sua dimensão física, convém tomar contato com os conceitos de "carga", "diferença de potencial", "energia estática", "corrente", "condutores", "circuitos" e "potência".

Prótons e elétrons são as duas partículas componentes do átomo que possuem uma específica propriedade: atraem-se reciprocamente e repelem-se entre si. Por convenção, diz-se que os prótons possuem uma carga positiva e os elétrons uma carga negativa. É esta força elétrica - uma das forças naturais, ao lado daquela gravitacional e magnética - devidamente "domesticada" e explorada pelo homem que está na base da indústria da eletricidade.

Tendencialmente, o átomo encontra-se em equilíbrio elétrico, i.e., com igual número de prótons e elétrons, os primeiros fixos no seu núcleo e os segundos movimentando-se em órbitas concêntricas ao seu redor ${ }^{5}$. Nesse caso, o átomo está "eletricamente neutro". Pode ocorrer, porém, uma quebra dessa estabilidade, consubstanciada na alteração do número de elétrons: por ação de certas forças, determinados elétrons podem deixar um átomo, "migrando" para a esfera de influência de outro. Esses átomos "desequilibrados" são chamados de íons, positivo aquele que ficou com excesso de prótons, e negativo o que adquiriu novos elétrons.

Como dito, a ionização ocorre normalmente na natureza pela ação de diferentes forças e causas mas também pode ser controlada e realizada de forma 
ordenada e em mais larga escala. Por meio da fricção, calor, luz, pressão ou magnetismo (cfe. infra), é possível "carregar" um corpo, i.e., dotar-lhe de excesso ou retirar-Ihe elétrons, fazendo com que adquira uma certa carga, positiva ou negativa. A intensidade da carga é medida em coulombs (C) e 1 coulomb consiste na carga de $6,28 \times 10^{18}$ elétrons.

Se a um corpo carregado acosta-se outro com carga de sinal contrário, fala-se em uma diferença de potencial entre eles e o fenômeno da atração de cargas contrárias criará no espaço adjacente uma força elétrica motriz (FEM ou voltagem), disposta em um campo elétrico. Esta força - medida em volts e existente apenas pelo fato da contigüidade de corpos com cargas diferentes, independentemente do fluxo de elétrons - é diretamente proporcional à intensidade das cargas e é chamada também de eletricidade estática.

Havendo um "meio de comunicação" qualquer entre os pontos com diferença de potencial, haverá um fluxo de elétrons, do ponto negativo para aquele positivo, até a plena estabilização dos pólos, que tendem a tornar-se eletricamente neutros, cfe. acima. Este fluxo ordenado de elétrons, de um pólo a outro deste caminho (o circuito), constitui a corrente elétrica, medida em ampéres (A), i.e., quantidade de cargas (elétrons) que passam em um determinado ponto por segundo $(1 A=1 \mathrm{C} / \mathrm{s})$. Já por aqui se pode intuir que a magnitude da corrente elétrica depende da força existente no circuito (em razão direta) e da resistência que o "meio de comunicação" oferece à passagem ${ }^{6}$ dos elétrons $^{7}$ (em razão inversa $)^{8}$.

Como dito, com a passagem da corrente elétrica, a diferença de potencial tende a ser eliminada, fazendo com que diminua e desapareça também a força elétrica. Assim, para que se mantenha contínua e constante a corrente elétrica, é necessário manter constante a diferença de potencial, o que se obtém com uma fonte de voltagem. Na figura abaixo, a fonte é uma bateria, indicada pela expressão "bat": 
Pois bem: onde entra a energia elétrica neste contexto ?

Se se tem presente a definição genérica de energia oferecida no início desta seção - i.e., de ela é a capacidade de realizar trabalho - e se se tem presente que o movimento dos elétrons é, exatamente, um trabalho, então pode-se dizer que a energia elétrica é aquela forma de energia que está presente na corrente elétrica. $A$ energia elétrica torna-se disponível para uso através da passagem da corrente elétrica pelos mais variados aparelhos e equipamentos dos consumidores que se conectam ao imenso circuito que é o Sistema Elétrico. Quando se "liga" um aparelho na tomada, por ele passa uma determinada corrente elétrica que proporciona ao equipamento energia correspondente. Esta energia é convertida, como já se disse, em calor, luz, movimento etc.

A unidade de medida da energia é o watt (W) que indica a quantidade de energia consumida ou gerada em um determinado instante ou - para usar a linguagem antes empregada - a intensidade com que determinado trabalho é realizado. Trata-se da "potência". Já a quantidade de trabalho proporcionada pela energia representa o consumo ao longo do tempo, ou, em outras palavras, a soma das potências em um certo arco temporal, medida em watt-hora $(\mathrm{Wh})$. Reitere-se: "potência" indica a grandeza instantânea de energia e "energia" os montantes de potência diluídos no tempo. A relação é íntima, mas os dois conceitos devem ser diferenciados ${ }^{9}$ pois uma mesma quantidade de energia pode ser consumida com intensidades diferentes.

No exemplo abaixo, que retrata o comportamento do consumo de energia elétrica do Estado de São Paulo em um dia normal, a potência é representada pelas diferentes linhas (que correspondem a inúmeros pontos ou instantes de consumo, 
medida em W), enquanto que a energia consumida é toda a área que se encontra abaixo das linhas $(\mathrm{Wh})$.

\section{Carga do Estado de São Paulo}

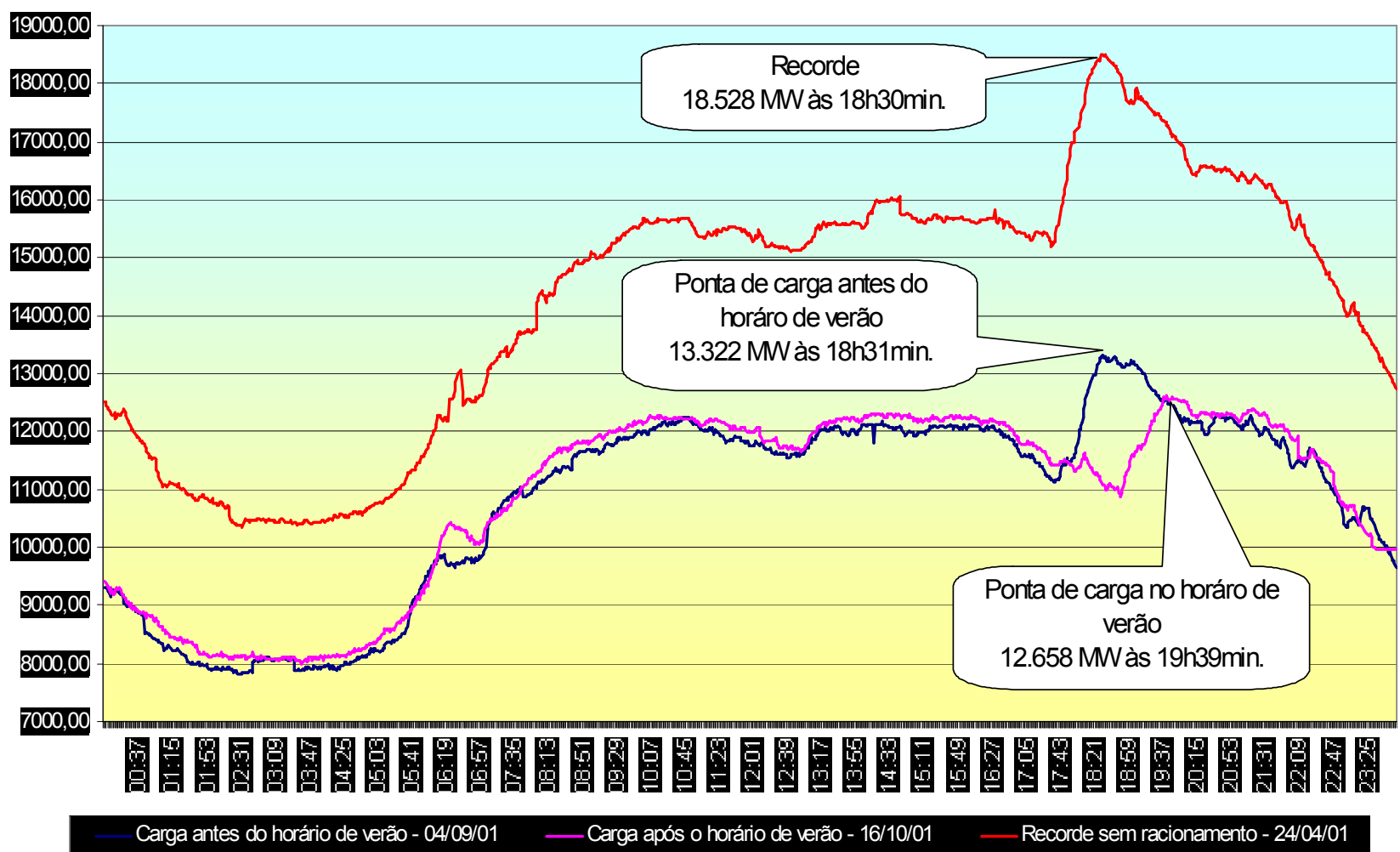

Como se verá oportunamente, os grandes problemas do setor elétrico encontram-se no âmbito da utilização da potência e não tanto na esfera do consumo de energia ao longo do tempo. Essa indústria deve ser dimensionada para atender aos chamados "picos de consumo" correspondentes ao instante do dia em que há a maior exigência de energia por parte dos consumidores.

Para encerrar essa breve apresentação, é importante frisar que não se deve confundir corrente elétrica com energia elétrica.

A corrente de elétrons, medida em ampères, move-se lentamente quando comparada com a velocidade do fluxo de energia, medido em watts (quase velocidade da luz); a corrente está presente nos metais e outros condutores, é parte da matéria (movimento de partículas atômicas), e, mais importante, nunca é 
"consumida" ou abandona um determinado circuito (lembre-se: os elétrons são continuamente "bombeados" de um pólo a outro pela fonte de voltagem ou gerador); já a energia ou potência é, sim, consumida por aparelhos elétricos e por isso deixa um circuito, transformada em outras formas de energia. Em termos pouco científicos, pode-se dizer que a corrente elétrica é o suporte físico da energia elétrica.

Com essas noções de física elementar é possível passar para o exame da indústria elétrica, a atividade que explora em bases estáveis e contínuas esses fenômenos.

\section{O SETOR ELÉTRICO: NOÇÕES GERAIS}

\subsection{As fases da indústria}

Os "serviços" ou atividades da indústria elétrica - referidas genericamente no texto constitucional - são, basicamente, três: a produção, a transmissão e a distribuição da energia elétrica até os centros de consumo.

A energia elétrica produzida nas usinas hidrelétricas, termoelétricas, eólicas etc (i.e., obtida a partir da transformação de outros tipos de energias contidos em determinadas fontes, cfe. supra) ${ }^{10}$, é levada pelo sistema de transmissão (as grandes torres metálicas situadas normalmente ao longo das rodovias) ${ }^{11}$ até os centros de distribuição (subestações), onde tem sua tensão ou voltagem rebaixada para ser entregue, via rede de distribuição, aos consumidores, no chamado ponto de entrega.

Consoante com isso, usinas geradoras e redes - compostas de fios e equipamentos acessórios como transformadores, subestações, barramentos etc. são as suas "instalações" básicas. A transmissão e a distribuição são as chamadas atividades "de fio" ("transporte", de forma imprecisa). 


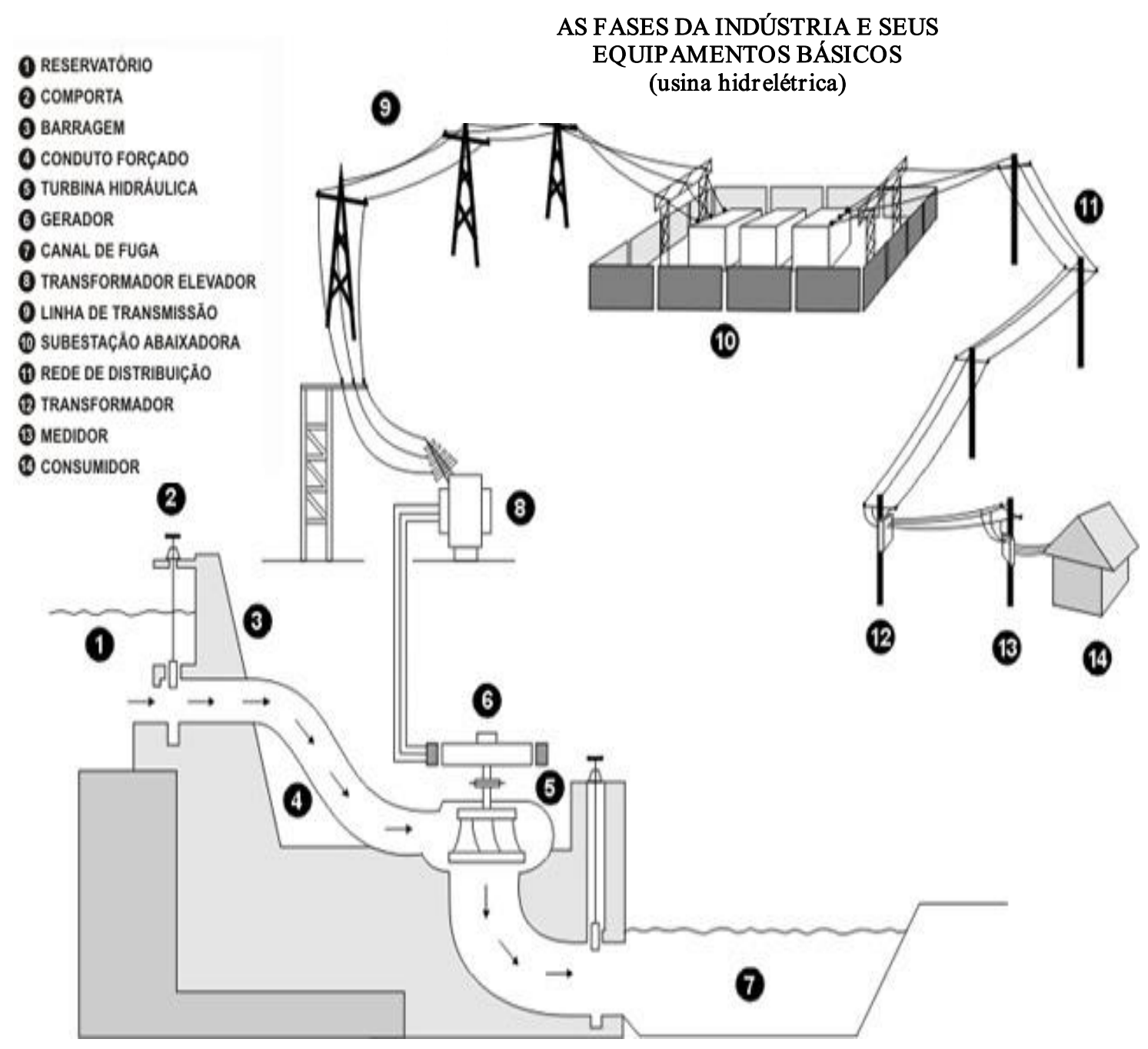

(figura 1)

A estas três atividades que exigem instalações e equipamentos, as normas do setor elétrico acrescentaram outra, de comercialização de energia. O comercializador "puro" não detém ativos de geração, transmissão ou distribuição nem maneja a utilidade mas apenas transaciona-a - com determinados consumidores e sob certos pressupostos - em operações de compra-e-venda. Não será, por isso, objeto de análise no presente estudo.

3.2 A característica básica: energia não se armazena e deve ser produzida na exata medida do consumo

As três funções a que correspondem equipamentos e instalações devem estar dispostas de tal sorte que atendam instantaneamente às exigências de consumo, na sua exata medida ${ }^{12}$. Isto porque não se pode conservar energia elétrica que, uma 
vez gerada, flui à (quase) velocidade da luz pelo sistema elétrico inteiro e é instantaneamente consumida ${ }^{13}$.

Essa é uma característica fundamental, de certo modo desconcertante, mas muito típica da energia elétrica e que determina importantes conseqüências na gestão da atividade. Não se pode - como ocorre em quase todas as outras atividades econômicas - produzir a utilidade para estocá-la e utilizá-la gradativamente na medida em que dela se precisa. Pode-se estocar o "combustível" ou a "fonte" como o petróleo, o gás, a água ou a biomassa, mas não a energia elétrica que o aproveitamento da fonte propicia.

Deixando de lado explicações e perplexidades físicas e técnicas, é importante ter presente que tal nota distintiva - conjugada a outra que será vista a seguir, i.e., a da interligação elétrica - faz surgir a necessidade de um sujeito que, não se limitando a gerar, a transmitir ou distribuir energia, tenha uma visão completa do sistema, desde o comportamento das unidades geradoras até o dos centros de consumo. Trata-se de um "operador do sistema", entidade (a tarefa hoje não está à medida de um só homem) que deve ter acesso prévio e, também, em tempo real a todas as informações acerca do comportamento da demanda ("carga" no jargão elétrico) de um dado sistema, bem como plena disponibilidade para coordenar a geração de energia nas usinas na medida da necessidade (coordenar ou determinar o "despacho") ${ }^{14}$. Como não se pode guardar energia elétrica nem se pode gerar em excesso (sob pena de comprometimento da estabilidade de todo o sistema), este operador do sistema deve garantir - sob certos pressupostos de segurança e economicidade, cfe. adiante - que a produção se iguale, a todo o instante, ao consumo.

Essa é uma primeira nota que sugere uma reflexão sobre a necessidade, função e extensão do planejamento no setor elétrico (cfe. infra). 


\section{TRAÇOS DISTINTIVOS DO SETOR ELÉTRICO BRASILEIRO. PREPONDERÂNCIA DA GERAÇÃO HIDRÁULICA E ALTO GRAU DE INTERLIGAÇÃO}

Passando da descrição das fases da indústria e de seu traço genérico fundamental para a caracterização específica do setor elétrico brasileiro, pode-se dizer que os seus elementos mais marcantes são dados

(a.) pelo tipo de fonte de onde provém a maior parte da energia elétrica - potenciais hidráulicos: normalmente - e cada vez mais - distantes dos centros de consumo; situados em bacias hidrográficas ${ }^{15}$ submetidas a diferentes regimes climáticos - complementares - e altamente interdependentes entre si; explorados normalmente por meio da construção de reservatórios com longos (e diferentes) períodos de regularização, e;

(b.) pelo imenso sistema interligado de transmissão de energia elétrica que perpassa a maior parte do território nacional, unindo os centros de produção com os centros de consumo em uma malha elétrica de tal modo configurada que se diz terem as usinas entre si uma interdependência operativa (cfe. adiante).

Consoante com isso, costuma-se dizer que o Brasil (mais precisamente: a parte economicamente mais ativa de seu território) possui um sistema elétrico interligado de grande porte, de base hidrotérmica onde predomina a geração de energia elétrica a partir de uma fonte renovável, i.e., da exploração dos potenciais hidráulicos. Embora este potencial seja ainda relativamente pouco aproveitado ${ }^{16}$, as usinas hidrelétricas - cujas dimensões variam de $12.600 \mathrm{MW}$ a menos de $1 \mathrm{MW}^{17}$ de potência instalada - respondem por cerca de $80 \%$ de toda a potência instalada no país. 
Essas duas características são graficamente visualizadas na figura abaixo.

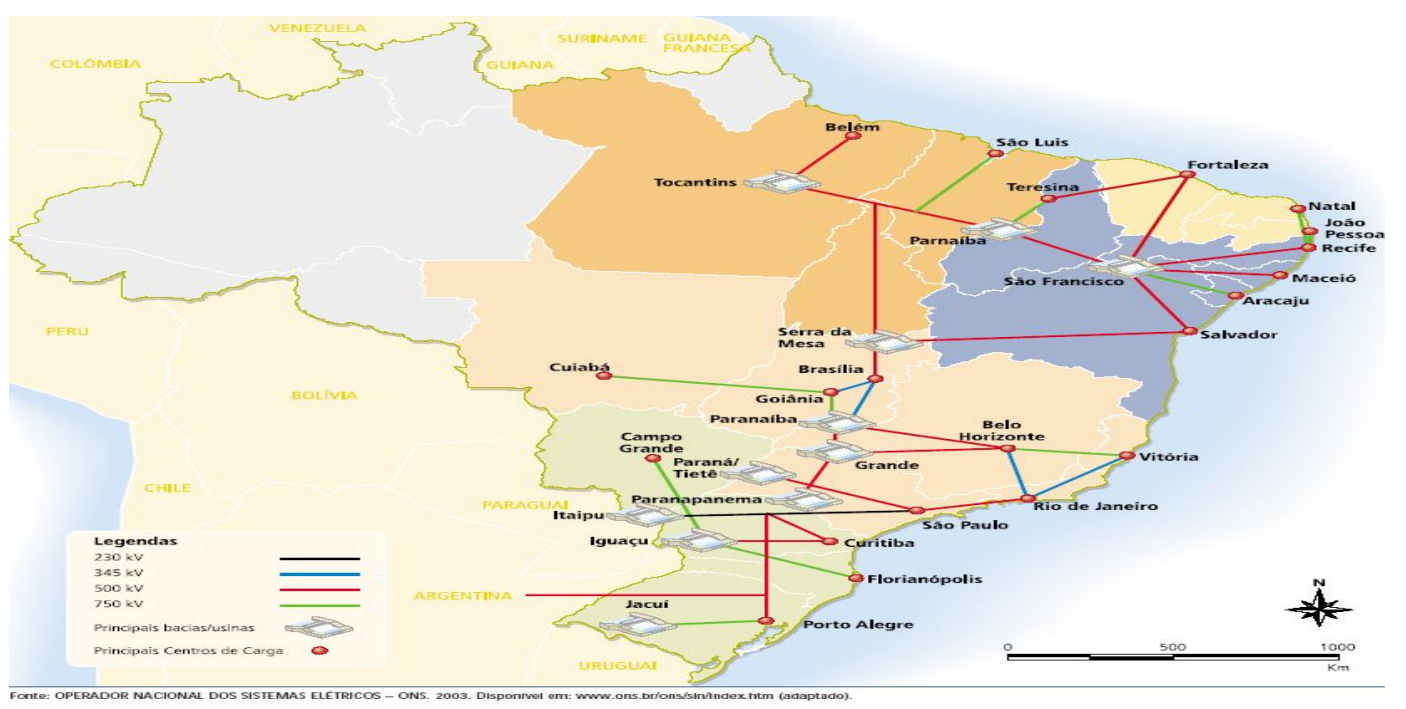

É necessário aprofundar estes dois pontos.

\section{CARACTERÍSTICAS DA GERAÇÃO, EM PARTICULAR, HIDRÁULICA}

Quando se fala em "água" como fonte de energia elétrica, refere-se, mais especificamente, ao potencial de energia hidráulica.

Juridicamente, o potencial hidráulico é considerado a se stante, como um bem. Tecnicamente, é caracterizado (i.) pela vazão hidráulica (movimento da água no rio) e (ii) pela concentração dos desníveis existentes ao longo do curso de um rio em um determinado ponto, de modo que se obtém o movimento da água em queda. A concentração desses desníveis pode ser natural (quando, por exemplo, o desnível está concentrado em uma cachoeira) ou obtido artificialmente (por meio de uma barragem ou por desvio do rio de seu leito natural, de forma a concentrar vários pequenos desníveis existentes ao longo de um rio).

Como é o potencial de energia hidráulica que é aproveitado pela usina hidrelétrica, para fins unicamente didáticos considerou-se útil separar o tratamento da "água" onde está o potencial, da usina que aproveita esta fonte. 


\subsection{Características da água como fonte de energia elétrica (potencial hidráulico)}

\subsubsection{A água é uma fonte renovável e ainda abundante}

A água é, como diz mesmo o texto constitucional (art. 176, par. único) uma fonte renováve/ de energia elétrica, além de não emissora de gases de efeito estufa (cfe. infra). E, dado o percentual com que ela participa da oferta deste insumo no Brasil, o país se caracteriza por possuir um dos mais altos índices de energia elétrica proveniente de fonte renovável. Enquanto o mundo apresenta uma média de 17\%, por aqui este percentual chega a $83 \%$, o que é uma grande vantagem competitiva.

A água não é a única fonte renovável de energia elétrica disponível. Além dela, são consideradas como tal a biomassa e o movimento de massas de ar, o vento, dentre outras menos significativas. Não são tidas por fontes renováveis de energia, por outro lado, o petróleo, o carvão, o gás natural e os minérios radioativos (urânio) usados também na geração de energia elétrica. Os três primeiros são chamados combustíveis fósseis e o urânio combustível nuclear.

A distinção entre fonte renovável e não renovável é dada pela velocidade de sua reposição em contraste com a velocidade de seu uso. Enquanto a água é reposta (pelas chuvas e demais precipitações atmosféricas) ciclicamente em um espaço de tempo compatível com seu uso, o carvão, o petróleo e o gás natural são materiais fósseis que levam milhões de anos para se formar, sem possibilidade de reposição que acompanhe o consumo.

Além de ser uma fonte de energia renovável, o potencial hídrico nacional ainda por explorar é bastante significativo, embora, em geral, muito distante dos principais centros de consumo ${ }^{18}$. Para que se tenha uma idéia, estima-se ${ }^{19}$ que o potencial hidráulico no Brasil possua uma capacidade de cerca 260 GW de energia, dos quais apenas $66 \mathrm{GW}$ foram efetivamente aproveitados, ou seja, algo em torno de $25 \%$. $\mathrm{Na}$ bacia amazônica, por exemplo, situam-se aproximadamente 105 GW de capacidade, com uma exploração que pouco passa de 0,5\%, i.e., 668 MW (números aproximados). 
Mas se essas são vantagens indiscutíveis da água, há certos fatores condicionantes externos que devem ser observados na geração de energia elétrica a partir dela.

\section{$\underline{5.1 .2}$ A água está sujeita a outros usos (uso múltiplo das águas)}

Com efeito, a água não é útil, apenas, para a indústria elétrica mas se presta a vários outros empregos pelo homem, como também salientado pela Constituição em diversos dispositivos.

Antes mesmo de servir para gerar energia elétrica, a água de nossos rios já era aproveitada de outras formas. Servia e serve para a navegação fluvial, i.e., para o transporte de pessoas e coisas (art. 22, inc. X); foi e é fonte de diferentes tipos de energia, a exemplo daquela mecânica para movimento de rodas e moinhos d'água. É ainda desviada para irrigação da lavoura (art. 42, ADCT), para usos residenciais, para consumo e também para criação de peixes e outras formas de vida aquática. $A$ água tem, em síntese, uma valência que vai muito além do seu aproveitamento para geração de energia elétrica, de tal sorte que esta última atividade deve ser levada a efeito de forma compatível com as demais.

Esse aspecto não importa somente no momento da construção da usina, mas permanece durante todo o período de seu funcionamento. Assim, a decisão de gerar energia em uma determinada usina não se funda exclusivamente na necessidade deste insumo, mas - à parte questões relativas à interdependência operativa entre usinas diferentes, cfe. infra - há de ser correlacionada com variáveis "externas" ao setor, tais aqueles relacionados com a navegação, proteção da fauna aquática, consumo etc.

\subsection{Características das usinas hidrelétricas}

Sinteticamente, uma usina hidrelétrica consiste no conjunto de obras e equipamentos cuja finalidade é a geração de energia elétrica, através de 
aproveitamento do potencial hidráulico existente em um rio. Uma usina "clássica" compõe-se das seguintes partes: barragem; sistemas de captação e adução de água; casa de força (onde estão a turbina e o gerador a ela acoplado) e sistema de restituição de água ao leito natural do rio. Como dito, a usina hidráulica nada mais faz do que aproveitar a energia potencial da água armazenada no reservatório (e a potência de uma usina hidrelétrica nada mais é do que o produto da altura da queda pela vazão da água).

Quanto ao processo, é relativamente simples: a água captada no lago formado pela barragem - quando esta existe - é conduzida até a casa de força através de canais, túneis e/ou condutos metálicos (condutos forçados). Ao passar pelas pás da turbina, fá-la girar, juntamente com um eixo em cuja extremidade está acoplado o gerador. Este é um magneto circundado por fios de cobre enrolados entre si. Girando-se o magneto ou a bobina de cobre (por força do movimento do eixo da turbina ao qual ele está acoplado) induz-se uma corrente elétrica nos fios, e tem-se a energia elétrica (energia mecânica transformada em energia elétrica pelo fenômeno da indução eletromagnética). Após passar pela turbina hidráulica, na casa de força, a água é restituída ao leito natural do rio, através do canal de fuga.

Ocorre, porém, que as usinas hidrelétricas não são, normalmente, consideradas isoladamente. Há vários fatores que levam a um tratamento conjunto delas. O primeiro é a hidrografia.

\section{$\underline{\text { 5.2.1 A interligação natural entre diferentes bacias, sub-bacias e rios }}$}

De fato, a hidrografia brasileira apresenta grande interligação entre rios, bacias e sub-bacias.

Essa característica faz com que as usinas hidrelétricas aí situadas - desde os mega-empreendimentos, como Itaipu e Tucuruí, de 12.600 e 8.125 MW, respectivamente, até os pequenos, de até $1 \mathrm{MW}$ - se encontrem "naturalmente" relacionados entre si pelas vazões de água antes mesmo de estarem integradas em um sistema de transmissão (no jargão, "acoplamento hidráulico"). 
Com efeito, tendo presente que (i.) os níveis dos reservatórios são elementos determinantes na capacidade de geração de energia elétrica de uma usina e (ii.) esses níveis são em boa medida determinados pela vazão do rio, e (iii.) a vazão do rio depende em grande parte dos manejos dos demais reservatórios situados acima daquele interessado, pode-se concluir que a geração de energia elétrica a partir de fonte hidráulica depende muito da operação das demais usinas situadas no mesmo complexo hídrico.

Considerando-se esse último aspecto e também a necessidade de gerar-se energia elétrica em harmonia com as exigências ambientais e ainda com a satisfação das demais necessidades atendidas pela água, tem-se que as decisões acerca da geração de uma determinada usina não são pautadas única e exclusivamente pelos seus próprios interesses econômicos e comerciais (usina isoladamente considerada). $\mathrm{Na}$ verdade, cuida-se de uma medida que necessita articular-se com inúmeras variáveis. Assim, por exemplo, é necessário avaliar se a geração (ou a sua falta) acarretará obstáculos à navegação fluvial, obstrução da reprodução de peixes, diminuição de água disponível para usinas que se encontram a jusante, risco de cheias etc (são as chamadas "restrições operativas").

\section{$\underline{5.2 .2}$ Outras características, apresentadas em confronto com as usinas} termoelétricas

Para finalizar esta brevíssima descrição dos aspectos mais salientes da geração de energia elétrica, convém fazer uma breve comparação entre aspectos técnico-econômicos das duas formas dominantes de geração, a hidrelétrica e a termoelétrica.

O processo de geração termoelétrica é semelhante àquele hidráulico, i.e., também se trata de movimentar um magneto entre fios (ou fios entre um magneto), a partir da rotação de uma turbina, gerando-se a energia elétrica pelo fenômeno da indução eletromagnética. Apenas que a acionar a turbina são outros "combustíveis" que não a água corrente. Aqui, o movimento é obtido pela expansão de elementos submetidos a altíssimas temperaturas e conduzidos até suas pás por dutos forçados. Trata-se ou do vapor da água superaquecida pela combustão de algum 
energético (carvão, óleo etc.) ou de gases superaquecidos (também resultantes de combustão). Em ambos os casos, é a energia térmica (calor) obtida a partir da energia química de alguma fonte primária que provoca o movimento. Troca-se a energia potencial da água pelo calor, para se obter a energia mecânica posteriormente transformada em energia elétrica.

As usinas termoelétricas, por sua vez, distinguem-se, segundo variados critérios $^{20}$, mas sobretudo, pelo combustível que empregam para gerar calor em processos de combustão - alguns deles referidos na Constituição, como o carvão, o gás natural, o petróleo e os minérios nucleares.

Certas usinas usam combustíveis fósseis, como o carvão, os derivados de petróleo ou o gás natural. Outras se valem da queima da chamada biomassa, i.e., de matéria orgânica de origem vegetal ou animal (bagaço de cana-de-açúcar, dejetos urbanos p.ex.). Outras, ainda, empregam combustível nuclear (aqui o calor não é obtido por combustão mas por fissão nuclear). O que as acomuna, no entanto, é o fato de que geram, de uma forma ou de outra, calor, o qual - agindo em um determinado meio - é por sua vez empregado para fazer girar as pás da turbina.

De modo geral, enquanto tanto térmicas quanto hidráulicas podem ter pequenas (pequeníssimas dimensões), são as usinas hidráulicas as unidades geradoras de maior porte. Para que se tenha uma idéia, uma grande usina térmica não ultrapassa os $2000 \mathrm{MW}$ de potência, enquanto que as grandes hidrelétricas podem superar os $10.000 \mathrm{MW}$, como é o caso de Itaipu.

Ocorre, porém que, normalmente, as maiores usinas hidrelétricas - ou os maiores potenciais hidráulicos ainda por explorar - situam-se longe dos centros de consumo, em regiões remotas do país (bacia amazônica, cfe. supra), enquanto que as termoelétricas, não dependendo de fatores naturais, podem ser construídas próximas da carga. A localização de uma usina importa, dentre outras coisas, para a determinação dos custos de transmissão associados a ela. Usinas distantes exigem linhas de transmissão mais extensas e, com isso, custos associados mais altos (nesse segmento). 
Um outro aspecto que muito diferencia as duas usinas é aquele relativo aos tempos de construção: enquanto as usinas termoelétricas exigem normalmente um prazo mais curto para a entrada em operação (2 a 3 anos desde a concepção), aquelas hidrelétricas consomem longos períodos desde a fase de estudos e inventário do potencial hidráulico ${ }^{21}$, passando pelos projetos construtivos e estudos ambientais, construção, formação do reservatório, até a entrada efetiva em operação comercial. Por conta disso, não é raro ter-se empreendimentos hidrelétricos concluídos em prazos superiores a 6 anos.

Quanto ao capital empregado, embora a indústria elétrica como um todo seja considerada de capital intensivo, os volumes econômico-financeiros requeridos por empreendimentos de exploração do potencial hidráulico são normalmente superiores àqueles movimentados por empreendimentos termoelétricos de mesma capacidade. Em termos absolutos, as usinas hidrelétricas são os empreendimentos que mais exigem mobilização de capital em toda a indústria.

Além de tomar muito tempo para maturação e ser de capital intensivo, um empreendimento hidrelétrico apresenta retorno do investimento em um prazo bastante longo. Isso se deve não apenas às duas características apresentadas, mas também ao fato de que o valor da energia elétrica transacionada quando a usina entra em operação tende a ser calculado em função, ainda, do custo da operação que é baixo (dado o não desembolso pelo combustível) e da vida útil provável da usina, que não raras vezes supera os 100 anos. Diferentemente, as usinas termoelétricas não têm tanta vida útil e possuem custos maiores na fase de operação.

Com efeito, outro elemento diferenciador diz respeito aos custos e riscos de operação. Enquanto a usina hidrelétrica trabalha com um combustível barato (quase sem custo), mas em certa medida aleatório, a água, e apresenta enorme custo de construção, a usina termoelétrica tem essa equação invertida: custa menos para construir e mais para operar, dado que necessita comprar o combustível que utiliza (petróleo, gás, carvão etc.). 
Também invertida é a equação ambiental: enquanto as usinas hidrelétricas causam grandes impactos ao meio-ambiente quando de sua construção e (comparativamente) menores efeitos na operação, as termoelétricas pouco agridem o ambiente para serem instaladas mas muito o danificam quando da operação, sobretudo se utilizados combustíveis fósseis, grandes responsáveis pela emissão dos gases de efeito estufa ${ }^{22}$. Enquanto a geração de energia elétrica a partir da água não provoca significativas emissões deste tipo de gases, as usinas térmicas a carvão são as principais responsáveis pela liberação de dióxido de carbono na atmosfera.

A construção das usinas hidrelétricas tem relevantes conseqüências sócioeconômicas e para o meio-ambiente. Ela comporta, via de regra, modificações no curso dos rios e a criação de um lago artificial, o reservatório, onde a água fica represada, pronta para a geração de energia elétrica. Este reservatório, de dimensões variáveis, provoca inúmeras alterações ambientais e, por vezes, sociais. As conseqüências mais importantes são a perda da biodiversidade (fauna e flora alagadas) ou de áreas cultiváveis e a alteração do microclima, com o aumento da umidade e das precipitações (chuvas) nas áreas adjacentes ao reservatório, bem como alterações da vida aquática (submetida a um regime diferente de vazões). Por vezes, de par com a perda de áreas cultiváveis, pode haver não negligenciáveis deslocamentos populacionais que suscitam o problema do reassentamento das populações atingidas pelas barragens.

Um outro elemento que diferencia as térmicas das usinas hidrelétricas é a eficiência energética, i.e., o quanto cada processo consegue aproveitar da energia "original" contida na fonte primária. Neste quesito, as usinas hidrelétricas são imbatíveis, pois apresentam um índice próximo aos 90\%: quase a totalidade da energia potencial gravitacional da água é transformada em energia elétrica. Já as usinas térmicas apresentam uma performance mais pobre: em média, conseguem aproveitar apenas cerca de $40 \%$ da energia química contida no elemento combustível (desconsidera-se a co-geração). Há muitas transformações envolvidas em um ciclo térmico tradicional: de energia química para energia térmica; de energia térmica para energia mecânica e desta, finalmente, para energia elétrica. Em cada uma dessas fases, há perdas ${ }^{23}$. 
Do ponto de vista operacional, há complementariedade entre os diferentes tipos de usinas que - como se verá - estão interligadas em um sistema. As hidrelétricas fornecem o grosso da energia elétrica consumida, enquanto que as térmicas, de operação mais cara, complementam a oferta de energia elétrica no parque gerador brasileiro.

Esta característica requer uma breve explicação.

Antes de ser comando propriamente jurídico, é uma diretriz de bom senso econômico a produção de energia elétrica ao menor custo disponível. Sob essa premissa, as usinas hidrelétricas operariam sempre e a plena capacidade, pois que seu custo de operação é mais baixo, dado o nenhum desembolso pelo combustível.

Ocorre, porém, que, além de barato, o combustível das hidrelétricas é aleatório e corre-se sempre o risco de que venha a faltar, independentemente do esforço humano. Por isso, a água dos reservatórios deve ser usada também em consideração a este elemento de risco, em benefício do consumo futuro. Em outras palavras, não se pode, simplesmente, esvaziar os reservatórios para atender à demanda de hoje e correr-se o risco de insuficiência de energia ou de ter de contar quase que exclusivamente com a cara (e ainda assim insuficiente) geração térmica no futuro.

Assim - e eis aqui um outro elemento que aponta para a necessidade de um planejamento - a decisão acerca de com qual mix energético (água ou combustíveis) gerar energia em um dado momento contém uma ponderação que equilibra economicidade (que aponta para a energia de fonte hídrica) e segurança de abastecimento futuro (que sinaliza o uso de usinas termoelétricas). Esse equilíbrio é tradicionalmente encontrado, no Brasil, através de técnicas e modelos matemáticos que indicam o "despacho ótimo" - i.e., a ordem de geração - que deve ser seguido a fim de se manter uma boa relação entre custo de operação e risco de abastecimento $^{24}$. 
Esse último aspecto encarece o fato de que as usinas, hidráulicas e térmicas, operam em coordenação, ou seja, integradas em um sistema. E tal é possível, sobretudo, em razão da configuração das redes de transmissão de energia no Brasil.

\section{Características da transmissão - a Rede Básica de transmissão e o Sistema Interligado Nacional - SIN}

Viu-se acima que as usinas hidrelétricas (e apenas elas) possuem um elemento de integração "natural", consubstanciado na conformação da rede fluvial brasileira.

Pois a esse fator espontâneo acrescenta-se outro, "construído", i.e., as redes de transmissão do SIN. Dada a sua configuração, pode-se dizer que no Brasil, a transmissão de energia não tem apenas a função de ligar a usina ao centro de consumo (ou à rede de distribuição) com um mínimo de perdas elétricas. Ela realiza uma tarefa energeticamente estratégica, qual seja, a de integrar unidades de geração de energia elétrica submetidas a diferentes condições de operação (em função de diversidades climáticas, hidrológicas, de acessibilidade de combustível, de situação técnica etc.), para o melhor aproveitamento possível de todas as potencialidades do sistema (fig. 2).

Fisicamente, compõem o SIN as regiões Sul-Sudeste, parte do Centro-Oeste, Nordeste e parte do Norte. São mais de $80.000 \mathrm{Km}$ de redes de transmissão ${ }^{25}$, com tensões que variam desde 130 até $750 \mathrm{kV}$. Em termos de território, apenas a Amazônia e parte do Centro-Oeste estão fora de sua cobertura e são atendidos pelo que se convencionou chamar de "sistemas isolados" ${ }^{26}$. Uma rede de transmissão é considerada integrante do SIN (Rede Básica ou Rede Complementar, cfe. infra), quando possui uma importância sistêmica, ainda que regional, ou seja, quando seu funcionamento (ou mal-funcionamento) não afeta apenas uma região específica, sem repercussões para as demais áreas do sistema elétrico, mas está relacionada com outras partes desse sistema.

De fato, a principal característica do SIN é que ele promove a interdependência entre a grande maioria das usinas de geração de energia elétrica, estejam ou não "naturalmente" interligadas pela hidrografia, sejam elas hídricas ou térmicas, e 
aproveita com isso as diferentes situações das diferentes usinas. Em um sistema interligado pode-se, por exemplo, "transferir" - dentro de certos limites, i.e., considerando as "restrições de transmissão" - a energia de uma região que a tem em abundância por estar em período de chuvas e com reservatórios cheios de água, para outra carente, por estar atravessando um período de seca, com reservatórios vazios. Ou ainda: pode-se "substituir" usinas que, por uma emergência, deixaram de gerar energia, por outras, mesmo que situadas no outro extremo do país.

Além de propiciar ganhos decorrentes das diferentes situações em que se encontram os inúmeros centros de produção de energia espalhados pelo território nacional, o SIN proporciona maior segurança operacional, ao aumentar as variedades de escoamento da energia elétrica gerada pelas usinas. Em outras palavras, é possível fazer chegar a energia elétrica aos locais onde é exigida por diferentes caminhos, bem como é possível minimizar mal-funcionamentos do sistema, por meio da adoção de "rotas alternativas" de escoamento da energia elétrica.

O potenciamento da geração bem como o aumento da segurança operacional do sistema tornam imprescindível uma operação coordenada das redes de transmissão que compõem o SIN. De fato, para atingir-se tais efeitos não se pode operá-las sob o horizonte restrito "usina/rede de transmissão/rede de distribuição", mas há de se ter uma visão conjunta do comportamento de todos os "corredores elétricos" conectados aos variados centros de produção e de consumo, cujos comportamentos também é necessário conhecer. Daí a necessidade da "Operação”.

\section{ATENDIMENTO DA DEMANDA DE ENERGIA ELÉTRICA COM SEGURANÇA, ECONOMICIDADE, QUALIDADE E GARANTIA DE DISPONIBILIDADE - A OPERAÇÃO}

\subsection{Introdução}

A idéia de "operação" não é de modo algum exclusiva da indústria elétrica, se se toma genericamente o termo, significando a atividade de produção e entrega da utilidade produzida, com o objetivo de atender-se com suficiência, qualidade e 
segurança à demanda respectiva. No setor elétrico, as usinas geram e as redes "entregam" a energia requerida pelo usuário, com certas características técnicas (padrões de segurança e qualidade) e a um certo custo. Pode-se, caracterizar, então, a operação como a atividade de manejo do sistema elétrico com o objetivo de atender plenamente o consumo imediato e futuro (próximo) de energia elétrica, com segurança, qualidade (e economicidade) e em observância de suas características e condicionantes.

O que torna o conceito de "operação" tão importante e complexo na indústria elétrica é o conjunto de suas características, algumas muito gerais, relacionadas com o comportamento do fenômeno físico (eletricidade e energia elétrica), outras próprias da configuração que essa indústria assumiu no Brasil - além da importância intrínseca da utilidade produzida, que exige sua oferta permanente e com atendimento a requisitos de qualidade e segurança muito estritos.

Em razão disso, a "Operação", envolve uma série de procedimentos concatenados entre si e diferenciados (i.) por fases da indústria: operação elétrica, operação energética e (ii.) no tempo: "Planejamento", "Programação", "Operação em Tempo Real", "Pós-Operação". Essas são todas fases do que se convencionou chamar de "Operação" 27 , de modo que há etapas anteriores e posteriores àquela de efetiva produção e entrega da utilidade.

Quanto ao comportamento do fenômeno físico, relembre-se o que ficou dito na Sub-Seção III.2.: a energia elétrica não se armazena e por isso deve ser produzida no exato momento em que requerida; e deve ser produzida na exata medida em que requerida, sob pena não apenas de um eventual desabastecimento mas de malfuncionamento do próprio sistema (a exata equivalência entre oferta e demanda não é apenas um desiderato econômico mas um requisito técnico de adequado funcionamento). Já por aqui se vê quão crucial na Operação do setor elétrico é a função de previsão da demanda (ou, mais tecnicamente, "Consolidação da Previsão de Carga").

Se a esses fatores físicos são acrescentados os elementos que fazem a complexidade do setor brasileiro, quais sejam (Seções IV, V e VI, supra): 
- Usos múltiplos da água ${ }^{28}$;

- A interdependência operativa das usinas hídricas;

- A interligação de vários centros de consumo com vários centros de produção por uma extensa rede de transmissão de energia - SIN,

é possível perceber mais diretamente a necessidade e a complexidade que a função "Operação" assume no $\operatorname{SIN}^{29}$ e intui-se que os agentes necessitam, para agir (gerando ou transmitindo energia), de algum tipo de coordenação e cooperação entre si (centralização de todos ou alguns aspectos da Operação e relativização da autonomia na decisão de quanto e como gerar energia).

A Operação envolve as três fases "físicas" da indústria elétrica, i.e., a geração, a transmissão e a distribuição de energia elétrica e ainda os consumidores. É-lhe necessário não apenas dominar a "capacidade produtiva" (geração) e de "escoamento" (transmissão) da utilidade, mas também conhecer a demanda respectiva.

Nada obstante a importância da fase da distribuição para a Operação do setor elétrico, diz-se que ela não é "Operada", no sentido técnico que este termo assumiu na literatura especializada. Com isso quer-se significar que a atividade de distribuição, conquanto dependente das fases anteriores e ao mesmo tempo relevante para a determinação delas, é submetida a um controle e planejamento diverso, a cargo de cada uma das empresas distribuidoras, por faltar-Ihe "relevância sistêmica ${ }^{30 "}$. Deste modo, ela é relevante para a Operação fundamentalmente como uma fornecedora de informações de mercado.

O cenário da Operação, assim, é circunscrito às fases da geração e transmissão. E, mais especificamente, opera-se a Rede Básica, a chamada Rede Complementar e as usinas "despachadas centralizadamente", i.e., aquelas cuja geração efetiva de energia é determinada pelo Operador Nacional do Sistema (cfe. infra). Este conjunto forma a "Rede de Operação do Sistema Interligado Nacional." As outras instalações de transmissão e as usinas integrantes do Sistema Interligado 
que não são despachadas centralizadamente não fazem parte da Rede de Operação, mas são monitoradas pela Operação e sofrem seu influxo.

Com tais objetivos e cenário, a Operação possui uma determinada estrutura, organizada por atividades e no tempo.

\subsection{Estrutura da operação}

A operação energética consiste no manejo da geração. Preocupa-se com as condições de oferta de energia elétrica no presente e no futuro próximo (5 anos, horizonte temporal mais longo para estudos de Operação). A expressão-chave dessa atividade é "despacho" (geração de energia) e seu objetivo é lograr o "despacho ótimo", i.e., a oferta da utilidade de forma suficiente, equilibrada entre o menor custo econômico possível e a garantia de abastecimento no horizonte fixado (minimização do chamado risco de déficit de energia).

Considerando as características do parque gerador brasileiro (hidrotérmico, com prevalência da geração de fonte hidráulica, mais barata, mas com um combusutível aleatório) este equilíbrio, pode vir formulado no modo de um dilema: usar água do reservatório no momento presente, para gerar energia a preços mais baixos, com acréscimo de risco no futuro, ou economizar água e gerar a partir de fontes térmicas, diminuindo o risco de déficit futuro mas encarecendo o preço atual (v. item V.2.2., supra).

Uma outra nota característica fundamental da operação energética brasileira é a sua configuração "cooperativa."

Sem adentrar demasiado na explicação deste ponto que já avança em análise jurídica, o que se pode dizer é que, independentemente dos efetivos critérios que determinam como será ordenado o despacho e quem o ordenará - critérios cujas escolhas possuem notáveis conseqüências comerciais e contratuais - haverá de existir indiscutivelmente coordenação técnica, consubstanciada em troca de informações e interações operativas entre os diferentes agentes interligados, o que por sua vez demanda algum grau de centralização e supervisão. 
No sistema brasileiro, esta exigência é satisfeita pela existência do Operador Nacional do Sistema.

A operação elétrica é o complemento daquela energética. As atividades, aqui, incidem sobre a rede de transmissão ${ }^{31}$ e envolvem a gestão adequada da energia elétrica (gerada segundo os ditames da operação energética) que por aí passa.

Enquanto a operação energética se preocupa com as condições da oferta de energia elétrica, a operação elétrica busca assegurar que esta energia chegará às fronteiras da Rede de Operação, com certas características de tensão e freqüência ${ }^{32}$ que a tornam apta para consumo. Cuida ela de evitar (ou minimizar) as hipóteses de interrupção do fornecimento e de garantir qualidade à utilidade.

Relacionada em boa medida com essas tarefas ou objetivos, está a exigência de segurança do sistema elétrico. Confunde-se parcialmente com a manutenção da qualidade pois que um sistema que não mantém sob controle a tensão e a freqüência é instáve/e corre sério risco de interrupção. Em todo o caso, a segurança do sistema elétrico envolve também outros aspectos ${ }^{33}$ que devem ser observados na operação, tais como respeito aos limites dos equipamentos e do sistema ${ }^{34}$, a minimização da possibilidade de ocorrerem contingências (curtos-circuitos, queda de linhas etc.) e a preservação da integridade do sistema no caso de ocorrências (bem como a possibilidade de sua rápida recomposição) etc.

Essas duas macro-funções (operação energética e operação elétrica) devem ser ainda desdobradas no tempo. Há fases da Operação que antecedem o despacho efetivo de energia e a gestão das linhas, bem como há etapas que lhe sucedem. Grosso modo, tem-se:

- Planejamentos:

- Planejamento Anual da Operação Energética.

- Planejamento da Operação Elétrica a Médio Prazo (anual).

- Avaliação Energética a Médio Prazo. 
- Planejamento Elétrico a Curto Prazo (quadrimestral).

- Planejamento Energético a Curto Prazo (Programa Mensal da Operação Energética).

- Planejamento Elétrico a Curto Prazo (mensal).

- Programação Diária da Operação Eletroenergética.

- Operação em Tempo Real.

- Pós-Operação.

\subsection{Atividades e resultados do planejamento}

Não é possível em um estudo que se propõe introdutório detalhar cada uma destas etapas, cuja complexidade é considerável. Em termos muito genéricos, podese considerar que todas as atividades antecedentes à operação em tempo real são preparativos seus que vão crescendo em densidade de conteúdo e exatidão de informações à medida em que mais próximas do momento do despacho. Os planejamentos de longo prazo dão as bases e diretrizes para aqueles de médio e estes, por sua vez, para aqueles de curto prazo. Ao mesmo tempo, aqueles mais recentes confirmam as projeções ou exigem revisão dos estudos de médio e longo prazo, de modo que todos juntos formam uma espécie de cadeia de estudos e análises que interagem constantemente.

Fundamentalmente, nas diversas atividades de planejamento (i.) compilam-se informações as mais variadas, relativas à geração, à transmissão e ao consumo; (ii.) projetam-se essas informações no tempo, construindo cenários futuros de comportamento do sistema (com simulações de funcionamento do setor elétrico nesses cenários ${ }^{35}$ ) e (iii.) obtém-se as informações necessárias para a tomada de eventuais medidas corretivas ou assecuratórias pelos agentes e ONS e, sobretudo, para subsidiar a operação em tempo real (ou para subsidiar planejamentos mais próximos dela no tempo), antecipando-se problemas e necessidades do sistema, para atendimento adequado da demanda. Em síntese: cada uma destas etapas concorre a seu modo para a otimização eletroenergética da operação em tempo 
real, além de sinalizar elementos importantes para a fase de Planejamento da Expansão do sistema (cfe. infra).

Para ficar em um exemplo, tome-se o Planejamento Anual da Operação Energética.

Elaborado anualmente, este planejamento alcança horizontes futuros de cinco anos, com detalhamento mensal para o primeiro ano. Neste horizonte, formula um cenário-base de comportamento das variáveis (cfe. supra), com a previsão de outros, alternativos, considerado um determinado critério de suprimento.

$\mathrm{Na}$ construção desses cenários, são consolidadas e analisadas diversas informações - provenientes dos próprios agentes, da ANEEL, do Operador Nacional do Sistema (ONS) e de outras instituições setorais - tais como:

- configuração provável do parque elétrico no futuro: novas usinas (somadas à capacidade produtiva daquelas já em operação ${ }^{36}$ fornecem a geração futura esperada para atendimento da demanda projetada, consideradas as perdas), índices de indisponibilidade de usinas e restrições operativas, cronogramas de manutenção de unidades geradoras, características físicas das usinas hidráulicas, dados técnicos das usinas termelétricas etc.

- evolução e configuração futura do mercado ou "previsão consolidada de carga de energia e demanda" (números de potência e consumo, patamares e tipos de carga)

- tendência de preços futuros da energia, incluindo custo incremental de operação para as usinas térmicas e a função de Custo do Déficit,

- evolução do comportamento dos reservatórios e dos rios (níveis iniciais dos reservatórios, volumes de espera, séries históricas de vazões médias mensais, energias naturais afluentes e vazões verificadas e previstas, restrições operativas hidráulicas) 
- configuração e comportamento da rede de transmissão no futuro, incluindo limites de transmissão entre as diversas áreas geoelétricas do sistema.

Recebidas essas informações, o ONS deve-as analisar e consolidar, estabelecendo concomitantemente o escopo do estudo e a configuração básica (cenário-modelo), ao lado das configurações alternativas nas quais as informações serão aplicadas. Concluído este trabalho preparatório, realizam-se as simulações, cujos resultados são objeto de novo estudo, para verificar sob quais condições atende-se ao mercado projetado ${ }^{37}$. Esses dados e resultados são disponibilizados aos agentes que os estudam e validam, para ulterior e final exame do ONS.

Ao cabo deste complexo de atividades, o ONS produz o "Relatório do Planejamento", um documento que apresenta as informações devidamente convalidadas $^{38}$, bem como os resultados obtidos. Destes, destacam-se dois: (i.) estratégias de medio prazo para a operação e recomendações de providências para melhorias e remoção de problemas e (ii.) elementos econômicos tais como: estimativas dos custos totais de operação, funções de custo futuro a serem utilizadas na otimização do sistema e no cálculo dos custos marginais de operação, curvas de aversão ao risco, análise dos custos marginais de operação.

Como se vê, é bastante complexa a atividade e as variáveis são inúmeras. O processo culmina no momento da "operação em tempo real".

\subsection{A operação em tempo real e pós-operação}

Ponto de chegada de uma longa cadeia de procedimentos e estudos envolvendo os mais diversos aspectos da geração, transmissão e mercado de energia elétrica, a operação propriamente dita é protagonizada por uma multiplicidade de agentes com diferentes funções e que se relacionam entre si por precisos protocolos e regras.

As coordenadas para produzir e conduzir a energia elétrica às subestações distribuidoras se materializam no documento chamado Programação Diária da 
Operação. A executá-la são os diversos centros de operação, tanto aqueles pertencentes aos agentes de geração e transmissão, quanto aos integrantes do Operador Nacional do Sistema.

As tarefas básicas da operação em tempo real são o despacho de energia e a gestão da rede (operação energética e operação elétrica, cfe. supra), em sintonia com a evolução da carga (load following).

Ao desempenhar essas atividades, o ONS, por seu Centro de Operação Central e seus Centros de Operação Regionais monitora em tempo real as condições de funcionamento e demanda do Sistema Interligado Nacional - trocando informações com os agentes locais e colhendo-as diretamente de seus sistemas - e, com base nas condições atuais e na programação prévia, dá ordens de despacho e de transmissão a serem executadas pelos geradores e transmissores.

Ao final de cada dia, o comportamento do sistema é avaliado pelo ONS que produz um Relatório de Ocorrências no qual são descritos os eventos mais significativos da operação e apresentados seus resultados. É a atividade de pósoperação.

Estas são as atividades que compõem a Operação.

Como se pode ver, ela é extremamente complexa, seja pelo número de informações que requer - proveniente de diversos entes, cobrindo uma ampla gama de atividades - seja pelos vários procedimentos que a compõem efetivamente.

Além disso a autonomia operacional dos agentes singulares inseridos neste quadro é bastante relativa. Por certo que o grau dessa autonomia não é ditado puramente por exigências técnicas ${ }^{39}$ e será objeto opções e decisões mais ou menos discricionárias, de modo que passa a ser (também) tarefa jurídica indicar e regular os critérios e as competências específicas que tocam a cada um, agentes e Operador. Mas é inegável que o adequado funcionamento do setor elétrico exige cooperação e sintonia entre as diferentes atividades e os diferentes agentes. 


\section{GARANTIA DA OFERTA FUTURA E EXPANSÃO DO SETOR ELÉTRICO - PLANEJAMENTO DA EXPANSÃO}

Lembre-se que, de modo geral, usinas e redes de transmissão requerem períodos não curtos para entrarem em operação; que demandam capital que normalmente não vem mobilizado com facilidade e instantaneidade. Lembre-se também que se trata de uma indústria de capital intensivo, na qual o sobreinvestimento tem conseqüências econômicas desastrosas para o investidor ou para o consumidor, de modo que idealmente a oferta deve acompanhar de muito perto a demanda, sem que se permita correr um risco do desabastecimento (dada óbvia a importância da utilidade). Considere-se, ainda, que a demanda por energia no Brasil é crescente e contínua, mesmo em períodos de baixo ou nulo crescimento econômico (em países subdesenvolvidos como o Brasil, isto ocorre pelo ingresso de novos usuários).

Para que a expansão da oferta se dê de forma ótima, exige-se, assim, planejamento. Planejamento da Expansão.

Dadas as notas características da indústria elétrica, os horizontes de planejamento da expansão costumam ser divididos em três blocos temporais: (i.) estudos de longo prazo, entre 20 e 30 anos, nos quais se estabelecem as linhas mestras de desenvolvimento do sistema, a composição esperada do parque gerador e dos grandes troncos de transmissão, os programas de desenvolvimento tecnológico-industrial e ainda metas para o horizonte de médio prazo; (ii.) estudos de prazo médio, entre 10 e 15 anos (Planos Decenal e Quinzenal de Expansão). Aqui é feito o equacionamento do atendimento ao mercado para os próximos 15 anos e o estabelecimento da alternativa de expansão do sistema elétrico, condicionada pelos resultados dos estudos de longo prazo. Por fim, tem-se (iii.) o planejamento da expansão de curto prazo, entre 3 e 5 anos, constituindo-se, sobretudo, em ajustes das decisões da alternativa de médio prazo a variações conjunturais como variação de mercado, restrições de investimento e cronograma de obras (normalmente é a revisão do Plano Decenal, o qual está em permanente contato com o Plano Anual de Operação). 
Esses estudos de planejamento costumam ter por tarefas avaliar a evolução, no tempo e no espaço, dos requisitos de mercado, programar os meios de produção e transmissão de energia elétrica mais convenientes para atendimento aos requisitos projetados, estabelecer diretrizes e metas a longo prazo, bem como avaliar condicionantes de curto prazo e, ainda, compatibilizar diretrizes e metas a longo prazo com condicionantes de curto prazo, através de revisões periódicas do plano de expansão.

Tudo isso com o objetivo de (a.) determinar meios necessários para garantir o atendimento futuro confiável e econômico aos consumidores de energia elétrica; (b.) minimizar risco de ociosidade prematura ou sobre-investimentos desnecessários que oneram os consumidores; (c.) propiciar prazos necessários para a programação dos recursos tecnológicos, financeiros, humanos e organizacionais compatíveis com as metas de expansão do sistema elétrico e, finalmente, (d.) conferir flexibilidade ao plano de expansão, tendo em vista as incertezas inerentes às projeções de mercado e de custos, bem como oportunidades e riscos detectados na elaboração ou na implantação do plano.

\section{UMA FASE NEGLIGENCIADA: A DISTRIBUIÇÃO DE ENERGIA}

Tradicionalmente, quando se trata de caracterizar um determinado setor elétrico, centra-se a atenção nos segmentos de geração e transmissão, supondo-se que a fase (fisicamente) final, da distribuição, tenha um comportamento e uma conformação padrão que pouco muda, em comparação com os traços mais cambiáveis da geração e da transmissão.

Independentemente de quanto possa ser acertada esta percepção, convém lançar algumas breves notas sobre a distribuição, visto ser ela um dos "serviços de energia elétrica" referidos pela Constituição e envolver não poucas "instalações", cfe. art. 21, inc. XII, b. Além disso, tenha-se presente que ela é tão importante quanto as demais na tarefa de propiciar energia elétrica para atender às necessidades nacionais e que o número de sujeitos que gozam desta utilidade essencial (energia elétrica) é diretamente dependente da capilarização das redes de distribuição no 
território. São estas instalações que conectam todo o sistema à unidade consumidora.

Tal como a transmissão, a instalação fundamental da distribuição é o conjunto de fios e postes que formam a rede elétrica. Esta rede, porém, transmite energia em baixa tensão e está, como dito acima, diretamente conectada às unidades consumidoras $^{40}$. Atualmente, as redes de distribuição espalhadas pelo país atendem a cerca de $95 \%$ das unidades que necessitam de energia elétrica.

Do ponto de vista econômico, costuma-se tratar a fase da distribuição como um monopólio natural.

Por esta teoria econômica, os custos de exploração e os preços a pagar pelos consumidores seriam maiores se fosse introduzida a concorrência neste segmento da indústria. A idéia que está por traz do monopólio natural é singela e envolve o conceito de economia de escala. Uma só estrutura (rede) pode atender a um número indeterminado de consumidores, com baixos custos incrementais (de adição de um consumidor novo). A duplicação - ou multiplicação - de redes em um mesmo território oneraria sobremaneira todos e cada um dos consumidores a elas conectados que não dividiriam o custo principal. No limite, poder-se-ia pensar na situação absurda de ter-se cada consumidor conectado ao sistema de transmissão por uma rede, por ele inteiramente custeada.

A teoria econômica que cuida da distribuição enquanto monopólio natural preconiza que o setor, por não estar sujeito à competição, seja especialmente regulado, para que se evitem abusos no exercício da atividade. A regulação a que se sujeita tal atividade é tanto de caráter econômico - para garantir a expansão e operação a preços compatíveis - como de caráter técnico - para garantir a qualidade do serviço de fornecimento.

Tecnicamente, o serviço de distribuição atende o fornecimento de energia dos consumidores de média e baixa tensão (34.5 kV, $13.8 \mathrm{kV}, 380 \mathrm{kV}, 220 \mathrm{~V}$ e $127 \mathrm{~V})$. Nas regiões mais desenvolvidas e nas áreas metropolitanas, cargas de maior porte 
podem também ser supridas pela distribuição primária, ou "subtransmissão", a 69 $\mathrm{kV}, 138 \mathrm{kV}$ e até $230 \mathrm{kV}$.

As companhias de distribuição são atualmente responsáveis pela preparação e planejamento dos projetos de extensão da rede (Planejamento da Expansão da Distribuição), realizando os trabalhos de construção necessários para o fornecimento de energia aos consumidores, juntamente com a operação e a manutenção de seu próprio sistema - de acordo com os níveis de qualidade de fornecimento adequados.

Este planejamento é composto pelos planos de expansão das redes de alta, média e baixa tensão, os quais possuem características específicas. No que se refere à tecnologia de planejamento de redes, esta área sofreu grandes avanços nos últimos tempos, procurando-se automatizar e controlar, mesmo à distância, as operações pertinentes, através de estudos apurados e com uso de modernos centros de operação, chegando-se hoje a uma preocupação crescente com o problema da qualidade da energia ${ }^{41}$.

Estas são, sucintamente apresentadas, as principais características técnicas e econômicas da indústria que devem ser consideradas pelo jurista em sua análise das normas pertinentes ao setor. A elas convém acrescentar uma outra característica que se poderia qualificar de "social" e que assume, hoje, a condição de obviedade.

\section{ABSOLUTA RELEVÂNCIA SOCIAL}

Considere-se o grande número de empregos gerados, a dimensão dos capitais mobilizados e dos recursos naturais estratégicos utilizados na indústria elétrica, o volume econômico-financeiro movimentando continuamente pelo setor, dentre outros fatores. Só por estes, ela mereceria um destaque pela importância que possui na economia do país.

Mas, por sobre todos eles está a importância intrínseca da utilidade produzida, da energia elétrica. E é tal esta importância que se pode dizer ser a energia elétrica 
um elemento constitutivo da sociedade e do Estado moderno, sem a qual suas instituições econômicas e políticas materialmente não funcionam.

Encarecer este aspecto hoje pode parecer truísmo, mas torna-se necessário, quanto mais não seja, para eliminar de vez uma discussão jurídica que incrivelmente - ocupou muito tempo de nossa doutrina em meados do século passado. No contexto da dicotomia entre serviços públicos e serviços de utilidade pública indagava-se se as atividades ligadas à produção e fornecimento de energia elétrica seriam necessárias (serviços públicos) ou meramente úteis (serviços de utilidade pública) à sociedade e, em última análise, à conformação estatal.

"Meramente útil" significava que a utilidade produzida poderia deixar de existir, sem que tal causasse mais do que eventuais desconfortos ou transtornos que não colocariam em risco a sobrevivência social e a coesão estatal. Parte da doutrina Pontes de Miranda, por exemplo - sustentava tratar-se de atividade que aportava somente comodidade à organização social.

Considera-se esta opinião equivocada e muito perniciosa para uma correta exegese constitucional. Sobretudo porque são tarefas como essa que mais de perto concorrem para a realização dos valores constitucionais estampados nos arts. $1^{\circ} \mathrm{e}$ $3^{\circ}$ da Carta e que por isso são dotadas por ela de um regime jurídico diferenciado.

Com efeito, dada a forma como se estruturou a sociedade contemporânea, é de se ter a produção, transporte e fornecimento de energia elétrica como atividades de absoluta relevância social e, assim, imprescindíveis.

Essa constatação isolada, no entanto, não importa em qualquer pré-julgamento de caráter normativo ou acerca da natureza jurídica da atividade. Sugere, apenas, que o Direito lhe empreste particular atenção, sem determinar aprioristicamente a sua forma jurídica. 


\section{CONCLUSÕES}

É chegado o momento de se colherem os pontos não jurídicos principais, para poder empreender-se - em outro momento - com frutos a análise propriamente jurídica.

- Energia elétrica é uma forma de energia e a indústria elétrica é uma das indústrias do setor energético. Obtém-se-a a partir do movimento das pás de uma turbina acoplada a um gerador, que converte a energia mecânica em elétrica através do fenômeno da indução eletromagnética; esta energia mecânica, por sua vez, é produto de formas anteriores de energia potencial, da água em queda; cinética, obtida com a combustão de certos produtos etc., chamados fontes de energia.

- As atividades da indústria elétrica são quatro: geração, transmissão, distribuição e comercialização; as três primeiras envolvem atividades de manejo físico da energia e instalações próprias. A comercialização consiste, apenas, na transação da utilidade (compra e venda).

- A energia elétrica deve ser produzida e transportada na exata medida em que é requerida e no exato montante demandado.

- A maior parte da energia elétrica produzida no Brasil provém de uma fonte de energia renovável, a água, mais precisamente o potencial hidráulico, cuja exploração ainda não atingiu $50 \%$ do total estimado; complementam o parque gerador sobretudo usinas termoelétricas que se valem de variados elementos: fontes não renováveis como os combustíveis fósseis (gás natural, derivados de petróleo, carvão mineral), e o combustível nuclear (urânio); fontes renováveis como a biomassa.

- A geração de energia a partir da exploração do potencial hidráulico tem as seguintes características básicas: 
- Possui dimensões que variam de $1 \mathrm{MW}$ de potência até $12.000 \mathrm{MW}$.

- Deve respeitar os demais usos da água, bem como ocorrer com a menor agressão possível ao meio-ambiente e às populações afetadas (esses dois últimos problemas se fazem sentir, sobretudo, na fase de construção).

- Deve realizar-se em atenção às demais usinas hidrelétricas que se encontram na mesma bacia ou sub-bacia hidrográfica.

- Possui longos prazos de construção e emprega larga quantidade de capital nesse processo.

- Tem uma vida útil longuíssima.

- Possui baixo custo de operação, mas vale-se de um combustível aleatório que, se usado de forma inadequada pode causar insuficiência de abastecimento futuro.

- Opera como fonte energética prioritária do sistema brasileiro.

- Por contraste, a geração termoelétrica:

- Tem dimensões que se situam, em geral, até $1200 \mathrm{MW}$.

- É menos agressiva ao ambiente na sua fase de construção, mas em geral muito poluente quando de sua operação.

- Consome tempos menores de construção e necessita de menos capital em comparação com uma usina hidrelétrica equivalente (o que não significa que não seja um empreendimento de capital intensivo).

- Possui uma vida útil mais reduzida.

- Possui custo de operação mais alto do que a hidrelétrica devido à necessidade de compra do combustível.

- Opera, no Brasil, de forma complementar às usinas hidroelétricas.

- A maior parte do território nacional está eletricamente interligada por uma rede de transmissão que conecta as diferentes usinas geradoras (hídricas 
e térmicas) aos diferentes centros de consumo. Trata-se do Sistema Interligado Nacional - SIN.

- Essa rede não apenas permite o fluxo de energia dos centros de produção aos de consumo, mas tem uma função energética estratégica: melhora a performance do parque gerador brasileiro, aproveitando-se das diferentes situações a que estão submetidas as usinas, e garante maior segurança na operação.

- Sua operação deve ser realizada com pleno conhecimento das possibilidades de geração, das exigências de consumo e das alternativas de "escoamento" da energia, i.e., a rede deve ser operada em benefício do sistema elétrico como um todo.

- Tanto as características da geração hidráulica quanto a existência do SIN exigem uma atividade de planejamento da operação. Esse planejamento necessita de uma enorme quantidade de dados relativos aos mais diversos aspectos da indústria (possibilidade e condições de geração, comportamento das redes de transmissão, necessidades de consumo etc.) e busca minimizar o custo total da operação e garantir o abastecimento (presente e futuro) com qualidade e em atendimento às exigências ambientais e de uso múltiplo das águas; em uma palavra, o planejamento da operação busca a otimização energética.

- Não é, porém, somente a operação que necessita de planejamento. Ele existe também na expansão do setor. Seu objetivo é a garantia, no tempo, da oferta em face da demanda, em condições ótimas, i.e., com suficiência, economia e qualidade no futuro (e sempre em atenção às condicionantes porventura existentes).

- A distribuição de energia: 
○ É uma atividade "de rede" que, porém, não individua um determinado setor elétrico de seus congêneres, dada a extrema padronização de sua configuração e operação;

○ É caracterizada economicamente como um "monopólio natural".

- Com todas essas características, a energia elétrica é uma utilidade indispensáve/para a Sociedade e o Estado modernos.

\title{
INTRODUCTION TO THE LEGAL SYSTEM OF ELECTRICAL INDUSTRY GENERAL PREMISES
}

\begin{abstract}
In this juridical-scientific study, the author discusses carefully the legal issue related to the legal regime of the electric industry in Brazil, with special emphasis on the contribution of the legal constitutional issue, which includes electricity, applicable principles to the species, demand for electricity, industry and social importance among others. In conclusively reference, crop, then, the main points not legal, relegating the typically legal analysis for another opportunity.
\end{abstract}

Keywords: Electricity. Electrical Industry. Constitutional Regime. Social relevance.

\section{NOTAS}

1 Doutor em Direito pela Universidade Federal do Rio Grande do Sul. Coordenador do Centro de Estudos de Serviços e Políticas Públicas Alternativas para o Setor Elétrico - CESPPASE da Universidade de Santa Cruz do Sul - UNISC. Este trabalho foi realizado no âmbito deste grupo.

2 A cana-de-acúçar, vegetal de alto potencial energético (contém muita energia química) é trabalhada para virar combustível automotivo - etanol - capaz de fornecer energia mecânica para a movimentação de veículos, ou açúcar, substância de alta concentração de energia química capaz de sustentar grandes quantidades de trabalho de um ser humano. $O$ resíduo deste processo - o bagaço da cana - ainda contém boa quantidade de energia química e pode ser queimado para se obter energia elétrica (entenda-se: pela sua queima libera-se a energia química da matéria orgânica que vem a ser transformada em calor, o qual, por sua vez, se transmuta em energia mecânica que, finalmente, "produz" energia elétrica por um processo que envolve várias etapas e materiais "coadjuvantes" e que se chama "geração termoelétrica", cfe. adiante).

3 Fontes de energia primária são os produtos energéticos providos pela natureza na sua forma direta, tais como petróleo, gás natural, carvão vapor, carvão metalúrgico, urânio, energia 
hidráulica, lenha e produtos da cana (melaço, caldo de cana e bagaço), resíduos vegetais, animais e industriais para geração de vapor, calor, luz solar, ventos. (BEN 2006).

4 Por energia secundária entendem-se os produtos energéticos resultantes dos diferentes centros de transformação e que têm como destino os diversos setores de consumo e eventualmente outro centro de transformação: óleo diesel, óleo combustível, gasolina (automotiva e de aviação), GLP, nafta, querosene (iluminante e de aviação), gás (de cidade e de coqueria) coque de carvão mineral, urânio contido no UO2, eletricidade, carvão vegetal, álcool etílico (anidrato e hidratado) e outras secundárias de petróleo (gás de refinaria, coque e outros).

É importante referir que também resultam dos processos de transformação produtos não energéticos, sobretudo do petróleo: produtos que, mesmo tendo significativo conteúdo energético, são usados para outros fins tais como graxas, lubrificantes, parafinas, asfalto, solventes e outros. Os elétrons não são atraídos para o núcleo, pela atração dos prótons, em razão de seu movimento centrífugo.

6 Na verdade, não se trata propriamente de passagem, como se o material fosse apenas uma "estrada" por onde um outro elemento circula, mas de liberação ou perdas sucessivas e constantes de elétrons do próprio condutor.

7 A resistência, por sua vez, depende do material de que é feito o caminho, e de suas dimensões. Se é tal que libera elétrons seus com facilidade, deixando passar o fluxo, é chamado de "condutor". Se, ao contrário, é um material que dificulta o fluxo, diz-se um "isolante".

8 É a Lei de Ohm, I=ER, onde I é corrente elétrica, medida em ampères, E é a força elétrica, medida em volts e $R$ é resistência, medida em ohms.

9 Os contratos de compra e venda do setor elétrico segregam, para fins comerciais, a potência do consumo.

10 Dentre os critérios mais comuns de classificação de usinas estão os seguintes.

Tipo de fonte a partir da qual se obtém a energia elétrica: (i.) usinas hidrelétricas (água); (ii.) usinas a gás natural; (iii.) usinas a carvão mineral; (iv.) usinas a diesel e demais derivados do petróleo; (v.) usinas a biomassa; (vi.) usinas nucleares; (vii.) usinas eólicas; (vii.) geração solar, dentre outras.

As usinas de ns. (ii.), (iii.), (iii.), (iv.) e (v.) são agrupadas sob o título de usinas termoelétricas porque um elemento essencial no processo de geração de energia elétrica é a energia térmica (calor), obtida ou pela queima dos respectivos combustíveis ou pela da fissão do átomo de urânio, no caso das usinas nucleares. Assim, têm-se usinas hidrelétricas, termoelétricas, eólicas e solares (essas duas últimas são, às vezes, denominadas como fontes alternativas).

As usinas termoelétricas dividem-se ainda segundo o elemento que faz girar a turbina (ou segundo o "modo de aproveitamento" da energia térmica resultante da combustão ou fissão): (i.) usinas de combustão interna; (ii.). usinas de combustão externa (a vapor). Nas primeiras, é o próprio combustível que, submetido à altíssima pressão e temperatura, entra em contato com as pás da turbina, provocando o seu movimento. Ou seja, a energia térmica obtida pela combustão é transformada "diretamente" em energia mecânica, sem fase intermediária. Nas usinas de tipo (ii.), o combustível é queimado para aquecer água que circula pelas tubulações da usina. Esta água se torna vapor que - sempre em altíssima temperatura e pressão - faz movimentar a turbina. Ou seja: a energia térmica liberada pela combustão não é transformada diretamente em energia mecânica, mas é "transferida" para a água que, em forma de vapor de alta temperatura, produz, finalmente, energia mecânica (movimento das pás da turbina). De regra, apenas as termoelétricas a gás e diesel são de combustão interna.

Característica da fonte quanto à reposição: (i.) usinas que empregam fontes renováveis; (ii.) usinas com combustível não renovável. São do tipo (i.) as usinas hidrelétricas, a biomassa, eólica e solar; de tipo (ii.) as demais, i.e., as que empregam combustíveis fósseis (carvão, gás natural e derivados de petróleo) e nuclear (urânio). A distinção baseia-se na articulação entre "velocidade de consumo" x "velocidade de reposição", como se verá adiante.

Característica do processo de geração: (i.) térmicas convencionais; (ii.) térmicas de ciclo combinado; (iii.) térmicas de co-geração. As térmicas de ciclo combinado envolvem um "duplo uso" do combustível e possuem, por isso, uma eficiência energética maior. Normalmente, o combustível primário é o gás que, depois de ser utilizado para a geração de energia elétrica na modalidade de combustão interna, ainda possui uma quantidade considerável de calor residual capaz de aquecer a água ao estado de vapor que, por sua vez, faz girar uma turbina de combustão externa. As usinas de co-geração possuem um funcionamento semelhante às térmicas de ciclo combinado, na medida em que também se aproveitam de calor residual do combustível primário (e por isso apresentam também uma maior eficiência energética). São diferentes, porém, pois empregam este calor em outros processos (por exemplo, de aquecimento) 
que normalmente estão agregados à própria planta. As térmicas convencionais, por sua vez, possuem, como o nome indica, um funcionamento simples, i.e., sem aproveitamentos residuais. Este é outro critério que diz respeito apenas às térmicas.

Modalidade de operação: (i.) operação integrada (usinas integradas ao sistema interligado nacional); (ii.) operação isolada (usinas conhecidas como geração distribuída - fontes locais junto às unidades consumidoras, normalmente operando sem controle do despacho central). Como se verá mais adiante, as usinas elétricas podem não abastecer direta e unicamente um centro de consumo, mas estar interconectadas em uma rede de transmissão que liga diversos centros de produção com diversos centros de consumo. Este tipo de organização existe para fazer com que fontes distantes possam distribuir energia a diversos pontos de consumo, tornando-se economicamente viáveis através da utilização do sistema de transmissão (economia de escala). A operação isolada, em que só uma usina atende diretamente um centro de consumo, é uma alternativa geralmente utilizada em locais remotos do país ("sistemas isolados", cfe. adiante) onde o custo de instalação de um sistema de transmissão não se torna atrativo.

Tipos de usinas hidrelétricas: há vários critérios de classificação. Os mais comuns são (i.) quanto à existência e altura efetiva da queda d'água; (ii.) capacidade ou potência instalada; (iii.) quanto à localização; (iv.) quanto ao tipo de barragem; (v.) quanto ao tipo de reservatório; (vi.) quanto ao tipo de turbina empregado.

Esses fatores são interdependentes. Geralmente, a altura da queda determina os demais, e uma combinação entre esta e a capacidade instalada determina o tipo de planta e instalação. Não há limites muito precisos para a classificação do tipo de queda e, portanto, os valores variam entre fontes e autores.

11 A tensão (voltagem) da corrente elétrica é aumentada para o transporte. Assim é porque desse modo se consegue transmitir de modo mais eficiente a energia elétrica, minimizando a quantidade de "perdas elétricas". As perdas elétricas, também conhecidas como "perdas ôhmicas", referem-se à parcela de energia elétrica que é transformada em calor ao ser transmitida. Isto se ao fato de que toda corrente elétrica que passa por um condutor (fio) encontra uma certa resistência do material e necessita "gastar" energia para superá-la. Esta energia não utilizável para o consumo mas para vencer a resistência é chamada de "perda elétrica" e é dissipada na forma de calor. Aumentando-se a voltagem, a "pressão" na corrente, diminui-se a quantidade de perdas elétricas.

$\mathrm{Na}$ verdade, a produção de uma usina (e do sistema) deve ser superior ao consumo, em razão das perdas. Ela é igual ao consumo mais as perdas.

13 Como já referido, a energia é uma constante no universo e por isso nunca é "consumida" mas transformada. Com efeito, tanto a "geração" quanto o "consumo" de energia são processos de cambiamento.

14 Há uma sutileza importante neste passo: o despacho pode ou não ser determinado pelo ONS. Se o despacho for técnico (como é o caso do Brasil), as usinas estão sob forte controle do operador. Nesta hipótese ele determina. Se o despacho for comercial (como é o caso da maioria dos outros países), há apenas gerência do operador, a qual consiste na acomodação das quantidades de energia que os diferentes geradores decidiram produzir em razão de seus compromissos comerciais, pelo critério do preço.

15 O Brasil possui 8 grandes bacias e mais de 80 sub-bacias. As bacias são (em ordem de potencial estimado em relação ao total nacional): Rio Amazonas (40,6\%), Rio Paraná $(23,5 \%)$, Rio Tocantins (10,3\%), Rio São Francisco (10,1\%), Sistema do Atlântico Leste (5,6\%), Rio Uruguai $(5,0 \%)$, Sistema do Atlântico Sudeste $(3,7 \%)$ e Sistema do Atlântico NorteNordeste $(1,2 \%)$.

16 Apesar da tendência de aumento de outras fontes, devido a restrições socioeconômicas e ambientais de projetos hidrelétricos e aos avanços tecnológicos no aproveitamento de fontes nãoconvencionais, tudo indica que a energia hidráulica continuará sendo, por muitos anos, a principal fonte geradora de energia elétrica do Brasil. Embora os maiores potenciais remanescentes estejam localizados em regiões com fortes restrições ambientais e distantes dos principais centros consumidores, estima-se que, nos próximos anos, pelo menos $50 \%$ da necessidade de expansão da capacidade de geração seja de origem hídrica.

17 Itaipu é a maior hidrelétrica do mundo, com potência de $12.600 \mathrm{MW}$. Havia, em setembro de 2003, cerca de 139 usinas hidrelétricas com potência superior a $30 \mathrm{MW}$, as quais respondem por cerca de $98,5 \%$ de toda a energia de fonte hídrica ofertada. O restante $1,5 \%$ é proveniente de 378 pequenos empreendimentos hidrelétricos (fonte Atlas de Energia Elétrica - ANEEL).

18 O que traz conseqüências técnicas e econômicas não desprezíveis. Quanto a isso, basta pensar na extensão das redes de transmissão de energia necessárias para integrar hidrelétricas situadas em zonas remotas como a Amazônia, ao Sistema Interligado Nacional. 
O potencial hidráulico total é o resultado da somatória da capacidade de todos os potenciais hidráulicos conhecidos. Este "conhecimento" do potencial e de sua capacidade, por sua vez, possui graus de profundidade, os quais dão origem a uma grande classificação entre potencial inventariado e potencial (meramente) estimado. Dos 260 GW, aproximadamente 177 GW já foram inventariados, sendo o restante apenas estimado.

O potencial inventariado contém aproveitamentos submetidos a um exame mais detalhado e inclui usinas em diferentes níveis de estudos além de aproveitamentos em construção e operação. Assim, o potencial inventariado é resultante da somatória dos aproveitamentos: (i.) apenas em inventário - estudo da bacia hidrográfica realizado para a determinação do seu potencial hidrelétrico, mediante a escolha da melhor alternativa de divisão de queda, que constitui o conjunto de aproveitamentos compatíveis, entre si e com projetos desenvolvidos, de forma a se obter uma avaliação da energia disponível, dos impactos ambientais e dos custos de implantação dos empreendimentos; (ii.) com estudo de viabilidade - resultado da concepção global do aproveitamento, considerada sua otimização técnico-econômica, de modo a permitir a elaboração dos documentos para licitação. Esse estudo compreende o dimensionamento das estruturas principais e das obras de infra-estrutura local e a definição da respectiva área de influência, do uso múltiplo da água e dos efeitos sobre o meio ambiente; (iii.) com projeto básico aproveitamento detalhado e em profundidade, com orçamento definido, que permita a elaboração dos documentos de licitação das obras civis e do fornecimento dos equipamentos eletromecânicos; (iv.) em construção - aproveitamento que teve suas obras iniciadas, sem nenhuma unidade geradora em operação; e (v.) em operação, i.e., que produzem energia para uso econômico.

Os empreendimentos em operação constituem a capacidade instalada (como dito, cerca de 66 GW).

O potencial estimado contém os potenciais em fases anteriores de estudo, i.e., (i.) potencial remanescente - resultado de estimativa realizada em escritório, a partir de dados existentes e sem qualquer levantamento complementar, considerando-se um trecho de um curso d'água, via de regra situado na cabeceira, sem determinar o local de implantação do aproveitamento; (ii.) potenciais individualizados, que são aqueles cuja estimativa foi realizada em escritório para um determinado local, a partir de dados existentes ou levantamentos expeditos, mas ainda sem qualquer levantamento detalhado.

O maior potencial total é o da bacia do Amazonas, com cerca de $105 \mathrm{GW}$ e um aproveitamento baixíssimo, de cerca de $668 \mathrm{MW}$, i.e., 0,6\%. Em segundo lugar, vem o potencial da bacia do Paraná, com cerca de $60 \mathrm{GW}$ de potencial total (dos quais $54 \mathrm{GW}$ inventariados) e cerca de 40 GW de capacidade instalada, ou seja, cerca de $73 \%$ de aproveitamento. Como se vê, a bacia do Paraná é muito explorada e, em termos nacionais, responde por quase $60 \%$ de toda a capacidade instalada (em seguida vêm as bacias do São Francisco e do Tocantins, com 16 e $12 \%$ do total da capacidade instalada nacional). Em termos absolutos, a bacia do São Francisco é a segunda mais explorada, com cerca de $42 \%$ de seu potencial inventariado já explorado).

v. nota 4.

v. nota 11.

De fato, essa afirmação acerca do potencial poluente deve ser restringida às térmicas que se valem de combustíveis fósseis, pois aquelas à biomassa e as usinas nucleares não apresentam alto grau de nocividade ao ambiente durante a operação.

Quanto à térmicas a carvão, gás natural ou petróleo, são, de fato prejudiciais ao meio ambiente. Atendo-se ao carvão, sua queima resulta na emissão de uma série de poluentes para o ar, tais como: cinzas, gases (SOx, NOx e $\mathrm{CO} 2$ ), "chuva ácida" e hidrocarbonetos

Dentre todos os resíduos, talvez o mais problemático seja o gás carbônico (CO2). Trata-se do gás que participa com a maior contribuição global para o aumento do efeito de estufa resultante de atividades econômicas (aproximadamente $60 \%$ do total). Por isso, as tarefas mais urgentes para as usinas térmicas a combustíveis fósseis são a redução dos impactos ambientais em concomitância com o incremento da eficiência energética.

As usinas de ciclo combinado e aquelas em modalidade de co-geração são mais eficientes do que os processos de ciclo simples, pois aproveitam duplamente o combustível inicial (gás, geralmente).

Consideram-se ainda neste processo as restrições operativas das usinas termoelétricas. Isto é, assim como as hidráulicas (cujas restrições operativas estão fortemente ligadas a questões físicas - defluência mínima, volume máximo operativo, etc.), as termoelétricas possuem restrições que impingem certas configurações de despacho: a chamada "geração mínima". Essa geração mínima irá definir se a usina terá um modo de operação tipo contínuo (operação 
na base da curva de carga, normalmente adotada para usinas hidroelétricas) ou tipo instantâneo (operação na ponta, normalmente adotada para usinas mais caras, que são despachadas apenas para cobrir os picos de demanda). A geração mínima pode ser originária de aspectos construtivos da usina (como nuclear por exemplo) ou de aspectos comerciais (contratos de suprimento de combustível, requerendo valores mínimos de consumo). Esse aspecto define a chamada "flexibilidade operativa" da usina.

As mais importantes instalações de transmissão são as linhas e as subestações.

As primeiras compreendem os cabos condutores, cabos pára-raios, torres, isoladores, ferragens e faixas de servidão; as subestações compõem-se de barramento, pátio, sistema de aterramento, capacitores e reatores, dispositivos FACTS e disjuntores, transformadores (de vários tipos), chaves de aterramento, seccionadores etc.

Nos Sistemas Isolados, em outubro de 2003, havia 345 centrais elétricas em operação assim distribuídas: (i.) Região Norte: 304; (ii.) Estado de Mato Grosso: 36; (iii.) Estados de Pernambuco, Bahia, Maranhão e Mato Grosso do Sul: 5. Tomados em conjunto, esses sistemas cobrem quase $50 \%$ do território nacional e consomem em torno de $3 \%$ da energia elétrica utilizada no País. Os mais importantes Sistemas Isolados, do ponto de vista da dimensão do consumo, são os que atendem às capitais da região Norte - Manaus, Porto Velho, Macapá, Rio Branco e Boa Vista - exceto Belém, que está interligada ao SIN. Nos sistemas de Manaus, Porto Velho e Macapá, a geração de eletricidade é hidrotérmica. Em Rio Branco a geração local é puramente térmica, com o suprimento complementado por meio da interligação, em 230 kV, ao sistema de Porto Velho. O sistema que atende Boa Vista e parte do interior do Estado de Roraima passou a ser suprido pela energia importada da Venezuela, por meio de uma interligação, em 230 kV, com o sistema da hidrelétrica de Guri, naquele país. A maioria dos sistemas do interior desses Estados é suprida por unidades geradoras a diesel. "Operação" com $O$ maíscula indicará esse complexo, enquanto que "operação" ou "operação em tempo real" alcançará apenas o momento da efetiva produção da energia elétrica. Cfe. supra. Essa necessidade de coordenação leva à uma interação, sobretudo, com os Comitês de Bacias, regulados pela Lei de Recursos Hídricos, Lei 9.433.

O Sistema Interligado Nacional é um sistema "interligado" mas não "integrado".

Os sitemas interligados caracterizam-se, como dito, por uma conexão entre forntes de geração e centros de consumo. O que os diferencia dos sistemas "integrados" é que nestes últimos, esta conexão é tal que não existem restrições relevantes de transmissão entre as diversas partes do sistema. Em outras palavras, em um sistema integrado todas as usinas podem atender a todos os pontos de consumo indistintamente. Em um sistema interligado, a troca de energia entre regiões é limitada pela capacidade de transporte dos "corredores" elétricos (linhas de transmissão).

Isto é, a operação efetiva da distribuição (não assim seu mercado) interessa primordialmente à região em que se encontra e as repercussões de seu funcionamento não se fazem sentir no Sistema Interligado Nacional. Essa dimensão local é também o motivo pelo qual certas redes de transmissão não fazem parte da Rede Básica.

Rede Básica e Rede Complementar.

Além delas há outras que não cabe explicar aqui.

Pode-se falar, em certo sentido, de um sistema inseguro que entrega energia com qualidade.

Restrições operativas das usinas; limites da rede para trocas energéticas entre bacias e regiões; limites operacionais dos equipamentos etc.

Essas simulações trabalham sobretudo com variáveis de produção de energia, visto que o consumo é tido por uma componente determinística (pouco exorbita das previsões), enquanto que a geração é uma componente probabilística (devido à aleatoriedade do regime de águas, como já dito).

Quanto à capacidade de produção de uma usina convém fazer um breve comentário, visto que esta grandeza não é obtida pela simples informação da potência instalada. O quanto uma usina vai produzir efetivamente depende de vários fatores além da capacidade das máquinas, controláveis ou não pelo agente ou pelo planejador. Diferente da capacidade instalada e da produção efetiva é ainda outra grandeza muito importante, que indica aos agentes seus quantitativos de energia para fins de contratações de longo prazo, a chamada "energia assegurada".

A questão pode melhor tratada fazendo-se uma distinção entre "elementos estáticos" e "elementos dinâmicos" da produção.

Os "elementos estáticos" de uma usina hidrelétrica consistem na (a.) potência ou capacidade instalada. É uma grandeza invariável, informada pelo fabricante da turbina, também chamada 
no jargão de "potência de placa"; (b.) potência efetiva. É a potência que leva em consideração a potência instalada submetida a três fatores técnicos, a saber, a queda nominal da usina (valor fixo, previsto no projeto de construção da usina), as possíveis taxas de indisponibilidade da usina e ainda o rendimento efetivo da máquina, sob determinadas condições ambientais de operação (pressão atmosférica, temperatura etc.). É menor do que a potência ou capacidade instalada; (c.) potência disponível. É aquela que depende da queda no momento considerado (queda líquida, que não se confunde com a queda de projeto), do nível do canal de fuga, da efetiva disponibilidade da máquina e ainda do número de máquinas em operação.

Os "elementos dinâmicos" estão relacionados com dados que não se referem diretamente à usina e suas máquinas mas às necessidades do sistema e as condições de combustível (água). Assim, eles são a carga a ser atendida, a previsão de hidrologia (considerando-se a aleatoriedade do combustível), o nível atual do reservatório (valores máximos e mínimos operativos de reservatório), a previsão de vazão vertida, de vazão turbinada, a vazão mínima defluente, a existência de eventuais impedimentos à operação advindos do uso múltiplo das águas, dentre outros.

A energia assegurada é um conceito muito típico do sistema brasileiro, relacionado com a preponderância de geração de base hídrica e com a alta dependência operativa entre as usinas, o que por sua vez, determinou a adoção de uma modalidade de despacho dita "centralizada" (cfe. o texto, acima), onde os agentes não têm ingerência na efetiva geração de suas usinas mas, por outro lado, necessitam possuir um montante certo (mínimo) de energia para poder comprometer em contratos de compra e venda de energia de longo prazo.

A energia assegurada pode ser definida como o montante de energia (não potência) atribuído à cada usina hidrelétrica do SIN, em função de uma série de procedimentos estatísticos e de simulação de condições de operação do parque gerador hídrico (incluindo 2000 séries sintéticas de vazões que são extrapolações das séries históricas das vazões dos rios brasileiros, calculadas desde 1931 e um certo risco de déficit de energia, atualmente fixado em $5 \%)$.

$\mathrm{Na}$ verdade, antes de ser uma grandeza imputável diretamente a cada usina ela é uma grandeza sistêmica. Reduz-se matematicamente todas as bacias e reservatórios (e usinas térmicas) a uma enorme "bacia única" e calcula-se a energia assegurada deste grande reservatório (energia assegurada do $\mathrm{SIN}$ ), imputando-se, depois, uma fração da magnitude encontrada por cada usina, segundo sua "energia firme" - esta sim é uma nota característica de cada usina e correspondente, grosso modo, ao quantum de energia que ela consegue gerar, considerando o período crítico de vazões (o pior período hidrológico, desde 1931) e uma operação que, nesse período, parte com o reservatório cheio e o depleciona até o máximo, sem reposição de água.

As usinas térmicas - para as quais a energia assegurada é também chamada de "garantia física" - tiveram de adequar-se a esse contexto e sua energia assegurada é definida como a energia proporcional à sua geração em um determinado contexto, considerando-se um custo marginal associado, i.e., o custo do contexto.

As funções do conceito de energia assegurada são, fundamentalmente, duas: (i.) indicar ao gerador seu limite de contratação de longo prazo (ii.) servir como critério de rateio do Mecanismo de Realocação de Energia (MRE).

Mais detalhadamente:

- Riscos de não atendimento à carga própria de energia no horizonte de estudo.

- Valor esperado dos déficits de energia.

- Valor esperado de geração térmica (para fins de CCC).

- Estimativas de intercâmbios entre regiões.

- Estimativas de evolução dos custos marginais de operação.

- Estimativas para intercâmbios internacionais.

- Evolução dos níveis de armazenamento do sistema com séries históricas de vazões.

- Conseqüências operativas decorrentes da análise dos casos alternativos ao caso base.

- Condições de atendimento à demanda máxima do sistema no horizonte de estudo.

- Necessidade de adequação do cronograma de manutenção de unidades geradoras para o atendimento à ponta do sistema.

- Índices estatísticos de confiabilidade: LOLP, probabilidade de déficit de potência; LOLE, valor esperado em horas de déficit de potência; EPNS, valor esperado do déficit de potência; EENS, valor esperado da energia não suprida; LOLF, valor esperado do número de ocorrências de déficit de potência; LOLD, valor esperado da duração do déficit de potência; Índices de sensibilidade da LOLP em relação a reforços de interligação. 
- Conseqüências decorrentes do atraso de obras da geração/transmissão.

Dentre elas:

- Descrição do caso base e de eventuais casos alternativos;

- função de Custo do Déficit;

- taxa de desconto adotada;

- cronograma de obras de geração considerados;

- cronograma das ampliações e reforços de transmissão que afetem os limites de intercâmbio;

- modelagem adotada para as interligações internacionais, incluindo custos e regime de operação;

- limites de intercâmbio entre áreas geoelétricas;

- relação das usinas simuladas individualmente;

- dados técnicos das usinas consideradas;

- custo incremental de operação para as usinas térmicas;

- geração mínima e geração máxima consideradas para as usinas térmicas;

- montantes mensais de energia e potência fornecidos para o sistema por usinas não simuladas individualmente;

- índices de indisponibilidade forçada e programada utilizados no estudo;

- volumes de espera para controle de cheias;

- relação das restrições operativas consideradas;

- valores de carga própria de energia e demanda utilizados;

- cronograma de manutenção de unidades geradoras;

- níveis iniciais de armazenamento dos sistemas.

Puras exigências técnicas não determinam, a priori, por exemplo, que os agentes não devem ter qualquer ingerência no despacho e que este deverá ser organizado por ordem de preço (como é o caso hoje).

Embora em certos casos especiais grandes consumidores podem estar conectados às redes de transmissão.

Os índices de qualidade são, basicamente: (a) DEC: representa o tempo médio durante o qual cada consumidor, em dado grupo ficou sem energia elétrica durante um certo período expresso em horas. (b) FEC: representa o número médio de interrupções sofridas pelo consumidor individualmente, em dado grupo, durante um certo período. (c ) DM: representa o tempo médio para o restabelecimento do fornecimento subseqüentemente às interrupções de fornecimento - expresso em horas. Os níveis aceitáveis destes índices são definidos de acordo com a densidade e a configuração dos sistemas em exame, e variam de 15 horas a 120 horas por ano de interrupção para DEC e de 20 a 90 interrupções por ano para FEC.

Recebido para publicação 13/11/2007

Aceito para publicação 04/12/2007 